\title{
COMB WARE CULTURE IN LITHUANIA: NEW EVIDENCE FROM ŠVENTOJI 43
}

\author{
GYTIS PILIČIAUSKAS ${ }^{1}$, DALIA KISIELIENË², GIEDRĖ PILIČIAUSKIENË³ \\ LUKAS GAIŽAUSKAS ${ }^{4}$, ALGIRDAS KALINAUSKAS ${ }^{5}$
}

\footnotetext{
${ }^{1}$ Department of Archaeology, Lithuanian Institute of History, Kražių 5, 01108 Vilnius, Lithuania, e-mail: gytis.piliciauskas@gmail.com

${ }^{2}$ Laboratory of Quaternary Research, Nature Research Centre, Akademijos 2, 08412 Vilnius, Lithuania,

e-mail: dalia.kisieliene@gamtc.lt

${ }^{3}$ Department of Archaeology, Vilnius University, Universiteto 7, 01513 Vilnius, Lithuania, e-mail: giedrepils@gmail.com

${ }^{4}$ Laboratory of Bedrock Geology, Nature Research Centre, Akademijos 2, 08412 Vilnius, Lithuania,

e-mail: lukas.gaizauskas0@gmail.com

${ }^{5}$ Department of Archaeology, Lithuanian Institute of History, Kražių 5, 01108 Vilnius, Lithuania, e-mail: algirdas.kalin@gmail.com
}

Šventoji 43 is one of eight Comb Ware culture sites known in Lithuania at present. The site was excavated in 2013 and 2014 and revealed a homogeneous pottery assemblage, which was classified as Comb Ware and was radiocarbon dated to 3900-3650 cal BC. As a result of this dating, it has been found that Comb Ware is the oldest pottery type to have been produced in coastal Lithuania. In fact, the pottery assemblage of Šventoji 43 also suggests that Comb Ware originates from a distinct phase in the pottery sequence of coastal Lithuania that both predates all other phases from Šventoji pottery bearing sites and has not been previously recognised in other assemblages. Zooarchaeological analysis has revealed that the site was occupied during the early spring and mostly used for fishing zander and pike in the lagoonal lake and for hunting seals and forest game. The unique character of the flint industry, which combined hard hammer percussion and bipolar knapping that resulted in the production of microliths on irregular blades, suggests that the local Šventoji 43 community had Mesolithic roots. Furthermore, this evidence supports the hypothesis that Comb Ware had reached Lithuania through intense contact between East Baltic hunter-gatherers rather than due to a mass migration of the population from the Northeastern Baltic. The much wider distribution of Finno-Ugric hydronyms, compared to that of Comb Ware sites gives an impression that some other Subneolithic pottery types in addition to Comb Ware might have been produced by Finno-Ugric speaking people.

Keywords: Comb Ware, Šventoji 43, coastal Lithuania, beginning of pottery production, FinnoUgric hydronyms.

Šventoji 43 yra viena iš aštuoniu Šukinès-duobelinès keramikos kultūros gyvenviečiu, šiandien žinomu Lietuvos teritorijoje. Ji tyrinèta 2013-2014 m. ir joje buvo surinktas homogeniškas keramikos rinkinys, klasifikuotas kaip šukine-duobeline keramika. Radiokarboniniu metodu ji datuota 39003650 cal BC. Atrodo, kad tokia keramika buvo pati pirmoji, imta gaminti Lietuvos pajūryje. Ši gyvenvietè rodo, kad pajūrio keramikos sekoje buvusi atskira, iki šiol nepripažistama šukinès-duobelinès keramikos fazè. Zooarcheologinè analizé atskleidè, kad gyvenviete buvo naudota ankstyva pavasari, jos gyventojai žvejojo sterkus ir lydekas lagūniniame ežere, medžiojo ruonius ir miško žvéris. Savita titnago industrija apèmè dvipolinę ir kieto mušimo technikas, iš netaisyklingu skelteliu gaminti mikrolitai. Tai rodo mezolitines bendruomenès šaknis ir remia ideja, kad šukine-duobelinè keramika Lietuvos teritorija pasiekè ne dèl masinès žmonių migracijos iššiaurès, tačiau dèl glaudaus Rytų Baltijos medžiotojų-rinkèju bendravimo. Žymiai platesnis finougrišku hidronimu negu šukinès-duobelinès keramikos paplitimas Lietuvoje leidžia manyti, kad kai kurie kiti subneolitinès keramikos tipai taip pat galèjo büti gaminti finougriškai kalbančiu žmonių.

Reikšminiai žodžiai: šukinè-duobelinė keramika, Šventoji 43, Lietuvos pajūris, keramikos gamybos pradžia, finougriški hidronimai. 


\section{INTRODUCTION}

The Comb Ware culture is mostly known from sites investigated in Finland, Karelia, Estonia and Latvia. Different variants of Comb Ware date to 5300-1800 cal BC, while its classical and most characteristic phase is known as Typical Comb Ware and dates to 4000-3400 cal BC (Nordqvist et al. 2012; Kriiska et al. 2017; Nordqvist 2018). In Lithuania, however, Comb Ware material is scarce: only 7 sites with pottery that may be classified as Comb Ware were known until 2013. Its impact on local cultural development was thought to have been minor (e.g. Rimantienè 1984; 1996; Girininkas 2000), although some of its undisputable influences on some types of local Subneolithic ${ }^{1}$ pottery have been noted (e.g. at Šventoji 26; Rimantienè 2005). However, up until this point Comb Ware culture as a separate phase had not been taken up into the pottery sequence. This was partly due to the fact that until recently Comb Ware culture received little attention and there was little discussion among Lithuanian archaeologists about how Comb Ware reached Lithuania and what its economy was based on. Archaeological data available before 2013 and 2014 was simply insufficient for this, as Comb Ware ceramics were very few and came from either multi-period, unstratified sites or from sites that have not yet been investigated by archaeologists. In 2013, however, a previously unknown Comb Ware site was discovered on the Baltic coast: Šventoji 43. It was realised that the site is of great scientific value because of the homogeneity of material culture and the preserved animal bones. In 2013 and 2014, an area of $67 \mathrm{~m}^{2}$ was excavated at the site. Research in the field was subsequently followed by analyses of ceramics, amber ornaments and production waste, lithics, osteological remains, plant macroremains and diatoms, stable isotopes, and finally, radiocarbon dating and age modelling. Today, the results of these investigations present an opportunity to further investigate the origin, chronology, and subsistence of Comb Ware culture communities at the southernmost fringes of its distribution. Therefore, the aim of this paper is to present the research results from Šventoji 43 and to evaluate the phenomenon of the Comb Ware culture in light of this new data.

\section{THE SITE OF ŠVENTOJI 43}

\section{Location and discovery}

Šventoji, which is situated on the Baltic coast (Fig. 1), is evidently among the most well-known Stone Age localities in the East Baltic because of the extensive excavations carried out at wetland sites with excellent preservation of archaeological finds, including wood, bone and textiles (Rimantienè 1979; 1980; 2005; Piličiauskas et al. 2012; Piličiauskas 2016). About 60 Stone and Bronze Age sites were discovered in this area either along the coasts or within the beds of ancient lagoons, lakes and rivers (Fig. 2). Most of them are dated to the Subneolithic or the beginning of the Neolithic (3200-2500 cal BC) and the different pottery found at these sites have been classified as Porous $^{2}$, Comb-like (only at Šventoji 26), Globular Amphora and Corded Wares. In 2013 and 2014, however, the first site from this area containing Comb Ware was discovered and investigated: Šventoji 43.

\footnotetext{
${ }^{1}$ In this paper we use the following periodisation of Lithuanian prehistory: Late Mesolithic 7000-5000/4000 cal BC, Subneolithic 5000/4000-3200/2900 cal BC, Neolithic 3200/2900-2000/1800 cal BC. The appearance of pottery shall be considered as the criterion for the beginning of the Subneolithic and likewise animal husbandry for the beginning of the Neolithic.

${ }^{2}$ Late Subneolithic pottery from the Šventoji region has been previously described as Narva or Narva Culture Ware, a term that is associated with the earliest pottery in the East Baltic (e.g. Rimantiene 1979; 1996; 2005). However, due to very large differences between these two ceramic types, we prefer to use the term Porous Ware for the Lithuanian pottery of post-Comb Ware period and thus avoid confusing it with much older pottery types.
} 


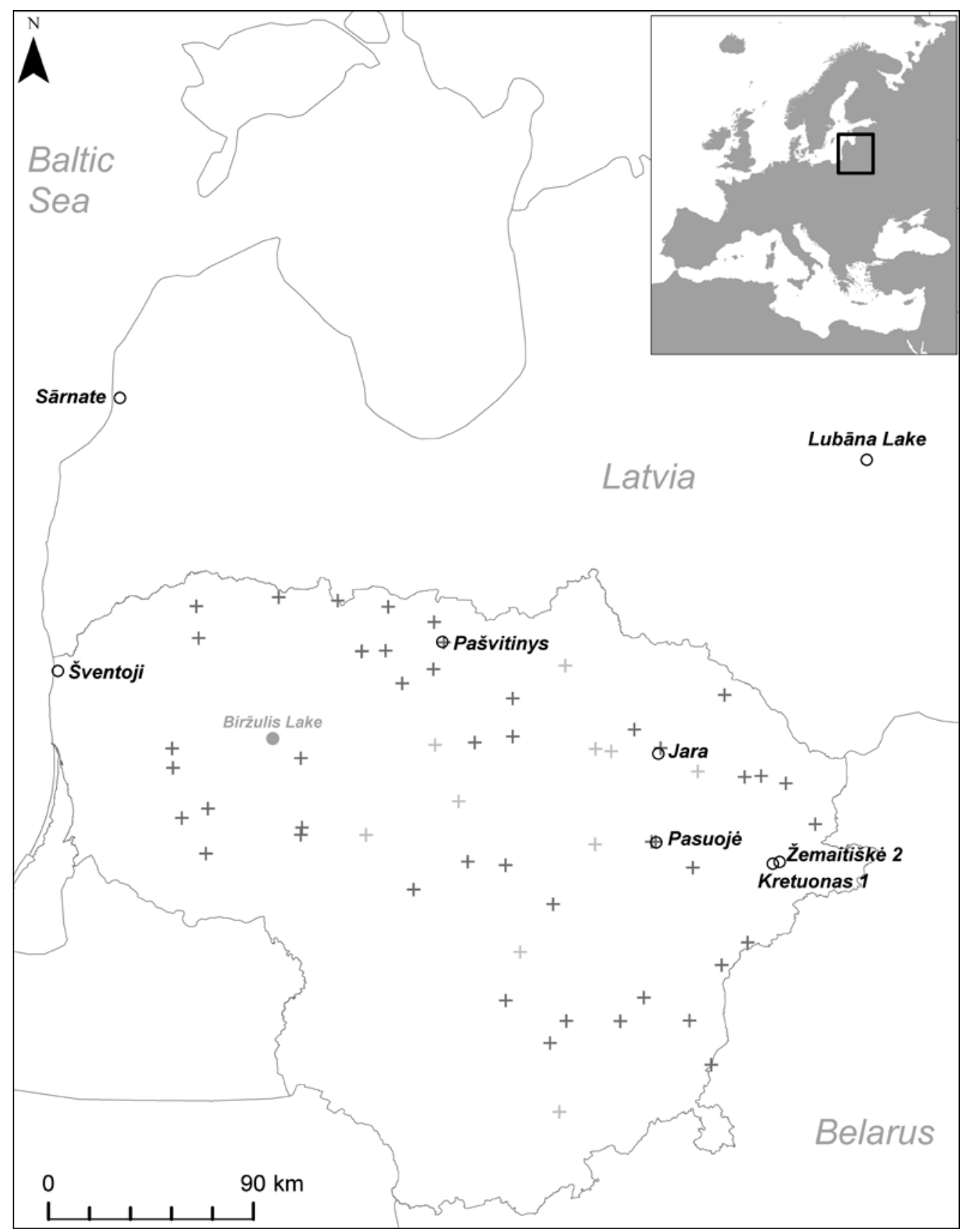

Fig. 1. Sites with Comb Ware pottery in Lithuania plotted against the hydronyms of Finno-Ugric origin. More probable Finno Ugric hydronyms are in darker colour than more questionable ones. Biržulis Lake region, which lacks Comb Ware sites, is also marked. Hydronyms were taken from Vanagas (1988). Drawing by G. Piličiauskas.

Šventoji 43 is one of the two southernmost archaeological sites situated between the modern settlements of Palanga and Šventoji. It lies on the eastern bank of the former lagoon or lagoonal lake
(Fig. 2). The site was discovered in 2013 almost 50 years later than the other well-known Subneolithic sites in the same area, such as Šventoji 1-6. The reason for this is that the land around Šventoji 43 avoided 


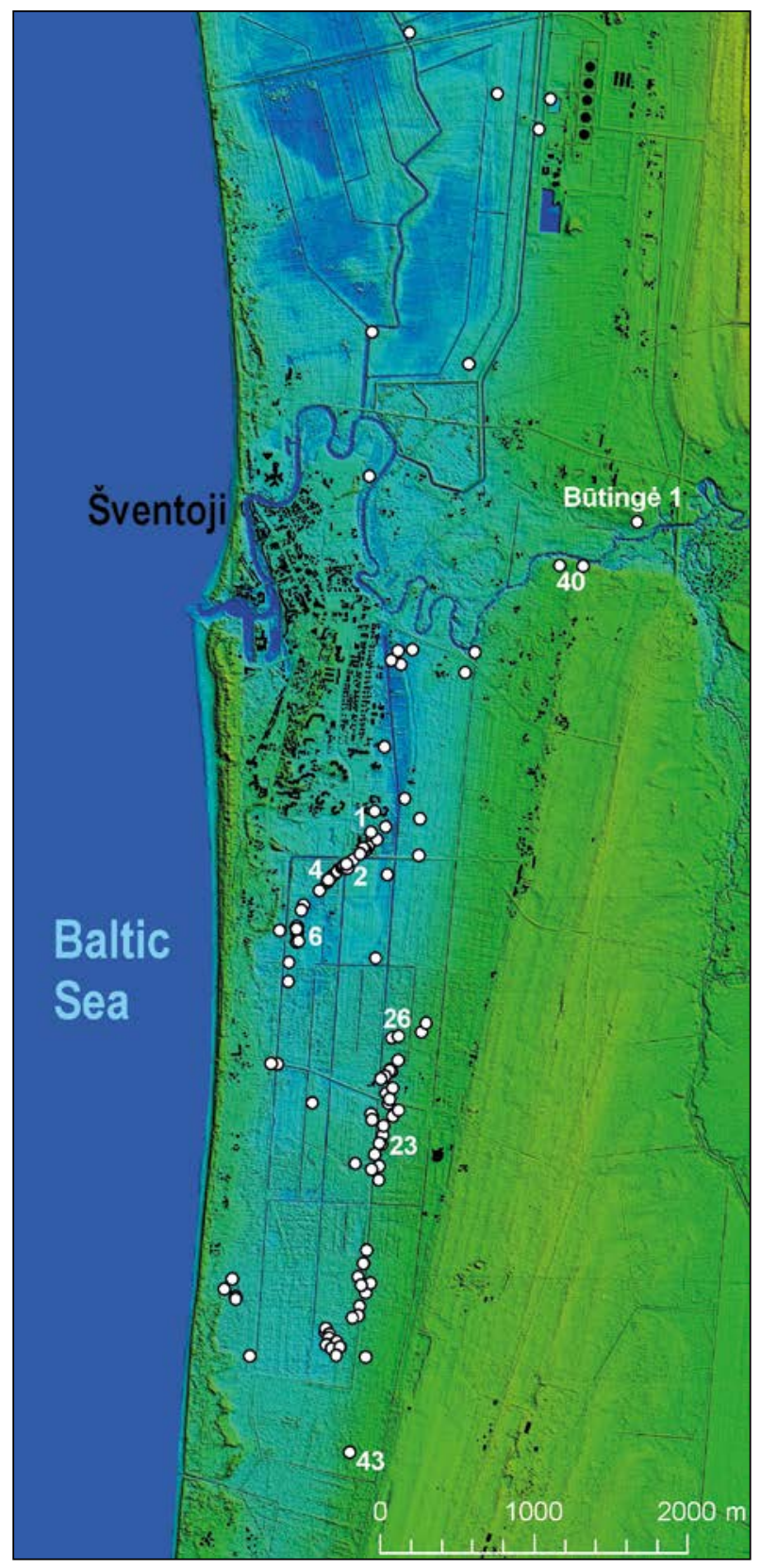

Fig. 2. Šventoji 43 and other archaeological sites known in Šventoji area and dated to 6000-500 cal BC. LiDAR based map. Drawing by G. Piličiauskas.

direct melioration in 1966-1967 that resulted in the discovery of most of the nearby wetland sites, yet left this site undisturbed. It was eventually found while carrying out a scientific program of systematic test-pitting along the eastern coast of the lagoon in 2013. During the survey, hundreds of $1 \mathrm{x} 1 \mathrm{~m}$ test pits were investigated along the eastern bank of the former lagoon, and an area of about $70 \mathrm{~m}$ by $40 \mathrm{~m}$ was designated as the newly discovered Subneolithic site. After the archaeological survey, it became clear that the site was situated on two barely distinguishable sandy elevations, reaching only $0.2-0.3 \mathrm{~m}$ high, which both form a peninsula-like protrusion westward from the low bank of the former lagoon (Fig. 3). The elevation of the modern surface at the site varies from 3.5 to $3 \mathrm{~m}$ a.s.l. and is more than 1-2 $\mathrm{m}$ higher when compared to the other Subneolithic dwelling sites at Šventoji, including Šventoji 23 and 26.

\section{Field research}

In 2014 it became apparent that the newly discovered site of Šventoji 43 had great potential to contribute to the improvement of the pottery sequence and progress towards a deeper understanding of the economy during the Subneolithic. It was decided to continue research and carry out more extensive excavations. Firstly, magnetometric and GPR surveys were carried out at the site in order to obtain information about the paleolandscape and potential dwelling structures. GPR survey was carried out with the aid of a Zond-12 controller (Radar Systems, Inc.) combined with 300 and $900 \mathrm{MHz}$ antennas. A GRAD 601-2 gradiometer (Bartington Instruments Ltd.) was used for conducting the magnetometric survey. Nevertheless, no significant insight was gained from these surveys. Only two geophysical anomalies possibly related to the Stone Age settlement were identified. However, during subsequent excavations both anomalies were confirmed to be caused by natural features in the landscape.

In order to learn as much as possible about the internal site structure without the resources available for excavation of the larger portion of the site, we excavated two $1 \mathrm{~m}$ wide trenches in 2014, the first being $35 \mathrm{~m}$ and the second $20 \mathrm{~m}$ long 


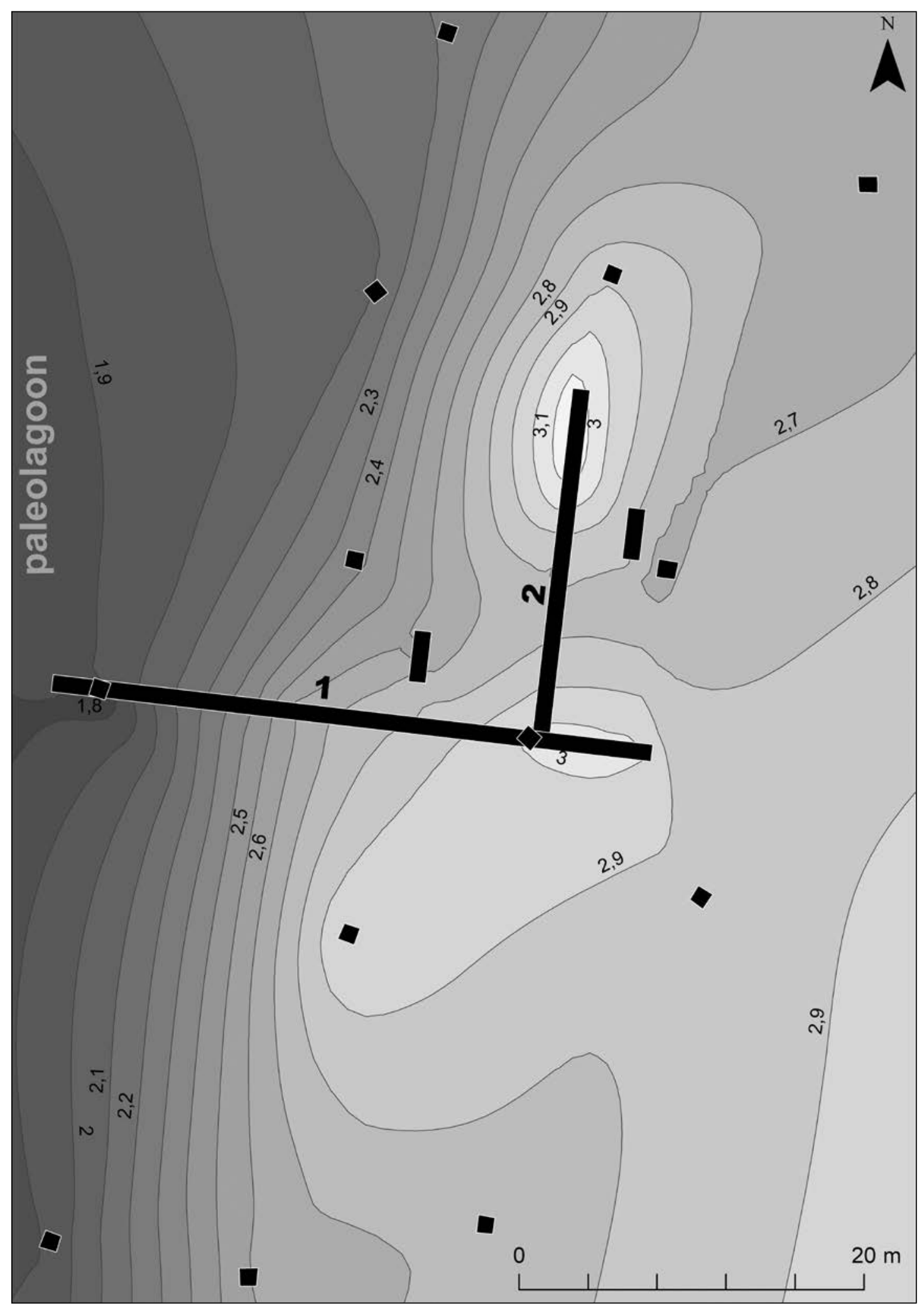

Fig. 3. Layout of test pits and trenches at Šventoji 43 site with the shaded topography of marine sand. Drawing by G. Piličiauskas. 


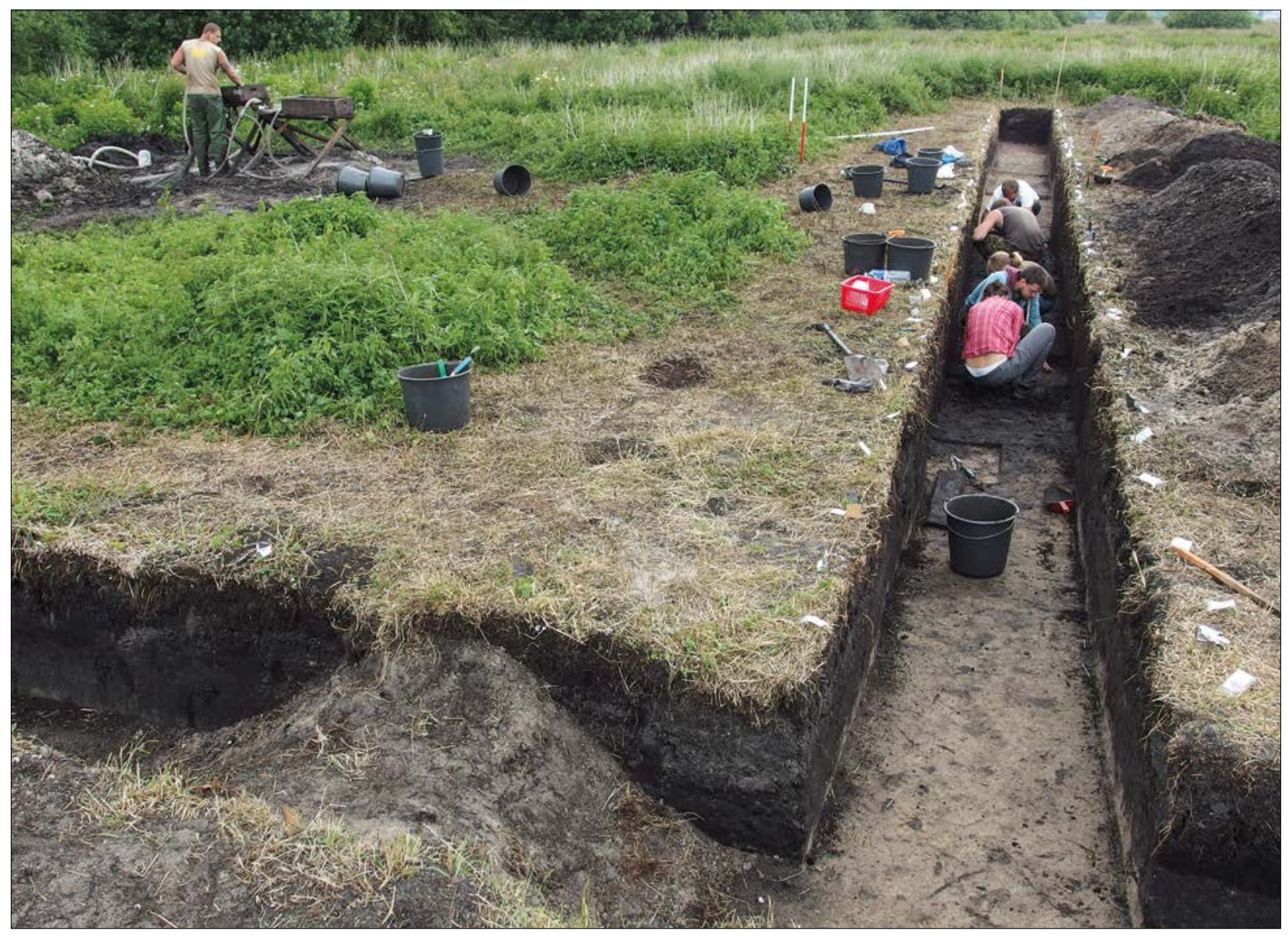

Fig. 4. View of the Šventoji 43 site during the excavation of trench 2. Photo by G. Piličiauskas.

(Fig. 4). They bisected the central and northern parts of the site in two directions and exposed the site's stratigraphic profile. In addition to these two trenches, two test pits were investigated in order to examine the aforementioned geophysical anomalies, each $1 \times 3 \mathrm{~m}$ in size (Fig. 3). A total area of $67 \mathrm{~m}^{2}$ was excavated in 2013 and 2014, which comprised less than $1 / 10$ of the area with a highly concentrated archaeological layer. Hence, the investigated section of the site is small, which should be taken into account when generalisations on the whole site are made.

During excavation the archaeological layer was divided into $0.5 \mathrm{~m}$ squares and removed with trowels in mechanical layers between 5 and $7 \mathrm{~cm}$ thick. The largest part of the archaeological layer was composed of humous sand, which was sieved through $4 \mathrm{~mm}$ mesh sieves. In the lowest area of the site (the western part of trench 1), the archaeological layer contained few finds and the soil was too peaty to sieve. Therefore, in that area all artefacts were collected by hand only.

\section{Stratigraphy and archaeological features}

In the eastern and higher-lying part of the site, the ploughed layer was $0.3 \mathrm{~m}$ thick and comprised of peaty fine sand. Underneath it, there was a $0.15-$ $0.25 \mathrm{~m}$ thick layer of highly decomposed peat, and below that was a $0.15 \mathrm{~m}$ thick layer of peaty sand (Fig. 5). All of these three lithological units contained archaeological finds, including stone, flint, and amber artefacts, pottery, fish and animal bones, and burnt 


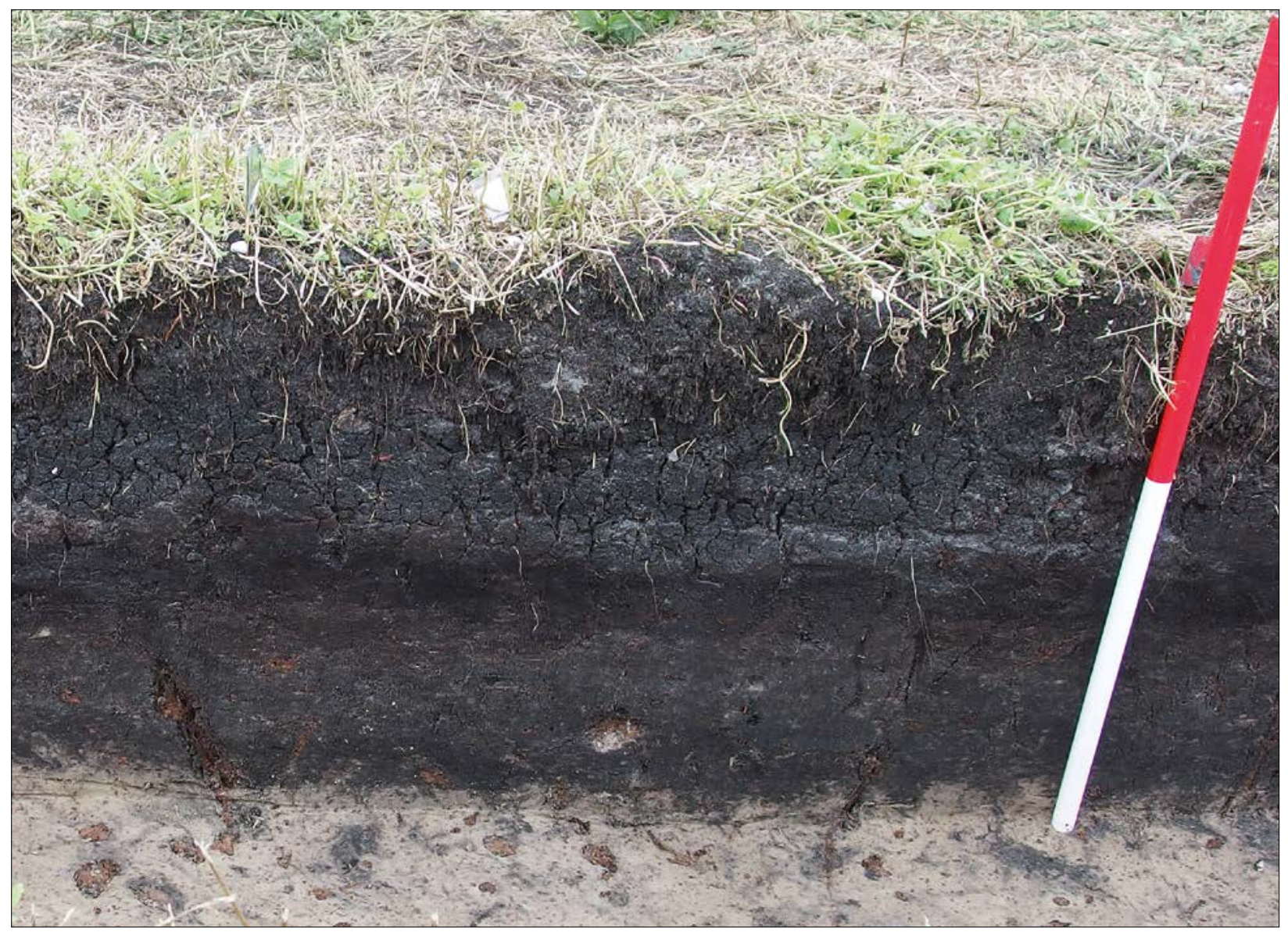

Fig. 5. Example of the stratigraphy in the upper part of the site. Photo by G. Piličiauskas.

hazelnut shells. The subsoil was composed of fine and medium Littorina Sea sand, and its surface was reached at a depth of 0.6-0.7 $\mathrm{m}$ (Fig. 6 and 7).

In the western, and coincidentally the lowest, part of the site, however, a different stratigraphy was recorded. The topmost layer was $0.3 \mathrm{~m}$ thick and was composed of ploughed peat and lacked archaeological finds. Below it, there was a medium-decomposed, unploughed peat layer $0.45-1 \mathrm{~m}$ thick. This peat layer was mostly deposited on dryland as was evident from the tree roots and stumps that were preserved in situ at the lowermost part of the peat, which was below the ground water table at about 2.3-2.4 $\mathrm{m}$ a.s.l. (Fig. 8). Contrary to what was expected, there was no stratified cultural layer in this area. Artefacts, such as animal bones and partly charred firebrands, were very few and concentrated in a rather thin horizon in the lower part of the peat at a depth of 1-1.1 m. Further down, there was fine and medium marine sand with peat interlayers containing small pieces of natural amber. It was replaced by gravely sand lacking any organics at a depth of about 1.3-1.4 m, which was followed by a layer of gravel at a depth of 2.3$2.4 \mathrm{~m}$ and most likely originating from wave-washed glacial till (Fig. 6). This information was obtained by drilling several boreholes after excavations of the trench were finished.

No dwelling structures, such as postholes, hearths or ditches, were uncovered during excavations. Only a heap of beach pebbles $0.4 \mathrm{~m}$ in diameter was found. In it there were 9 pebbles of different sizes, between $5-15 \mathrm{~cm}$ in diameter. The pebble heap was situated 


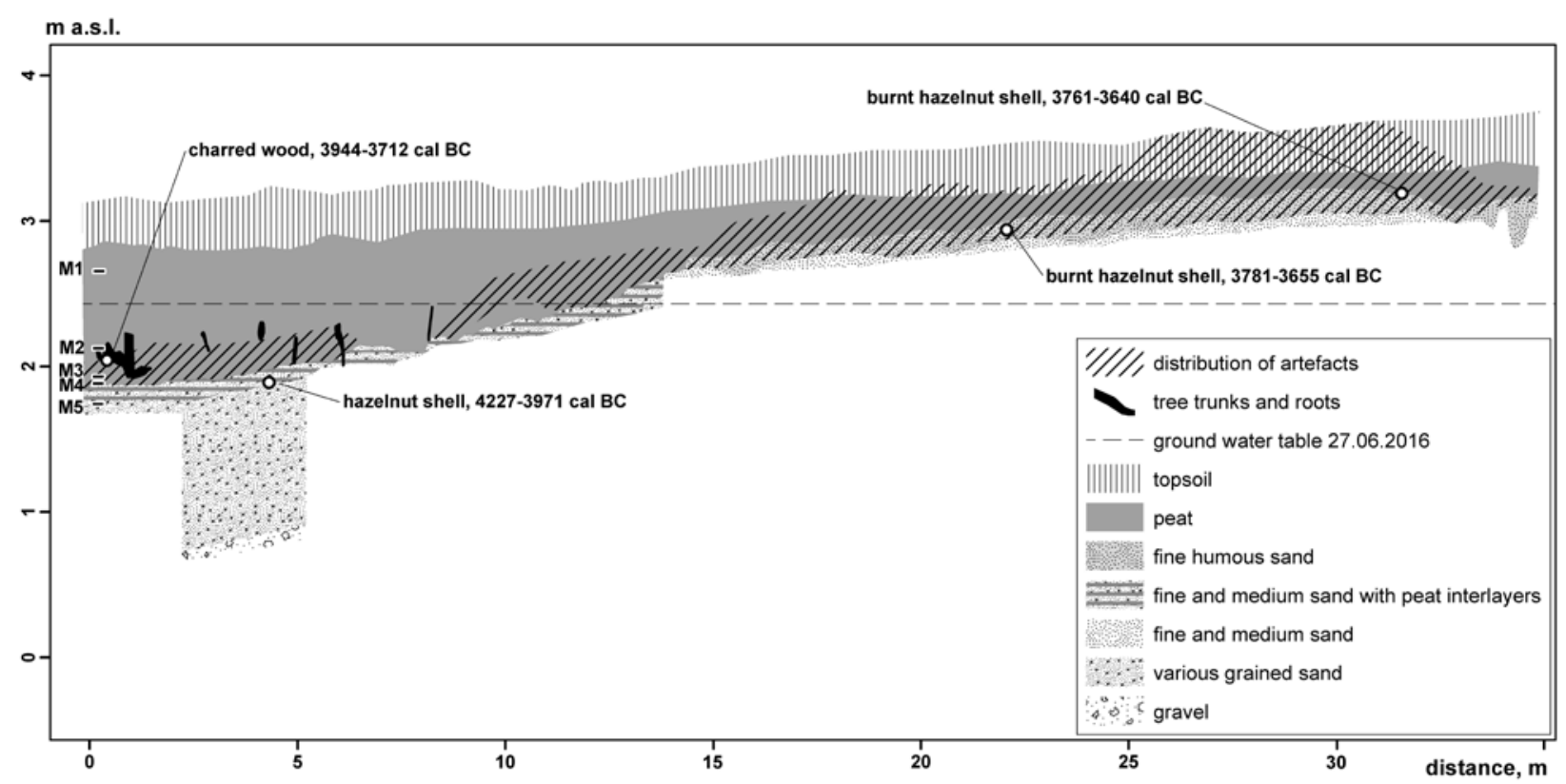

Fig. 6. Stratigraphic profile of the northern wall of trench No 1 exaggerated by a factor of 3.5 with plant macro-remain samples (M1-5) and radiocarbon dates marked. Drawing by G. Piličiauskas.

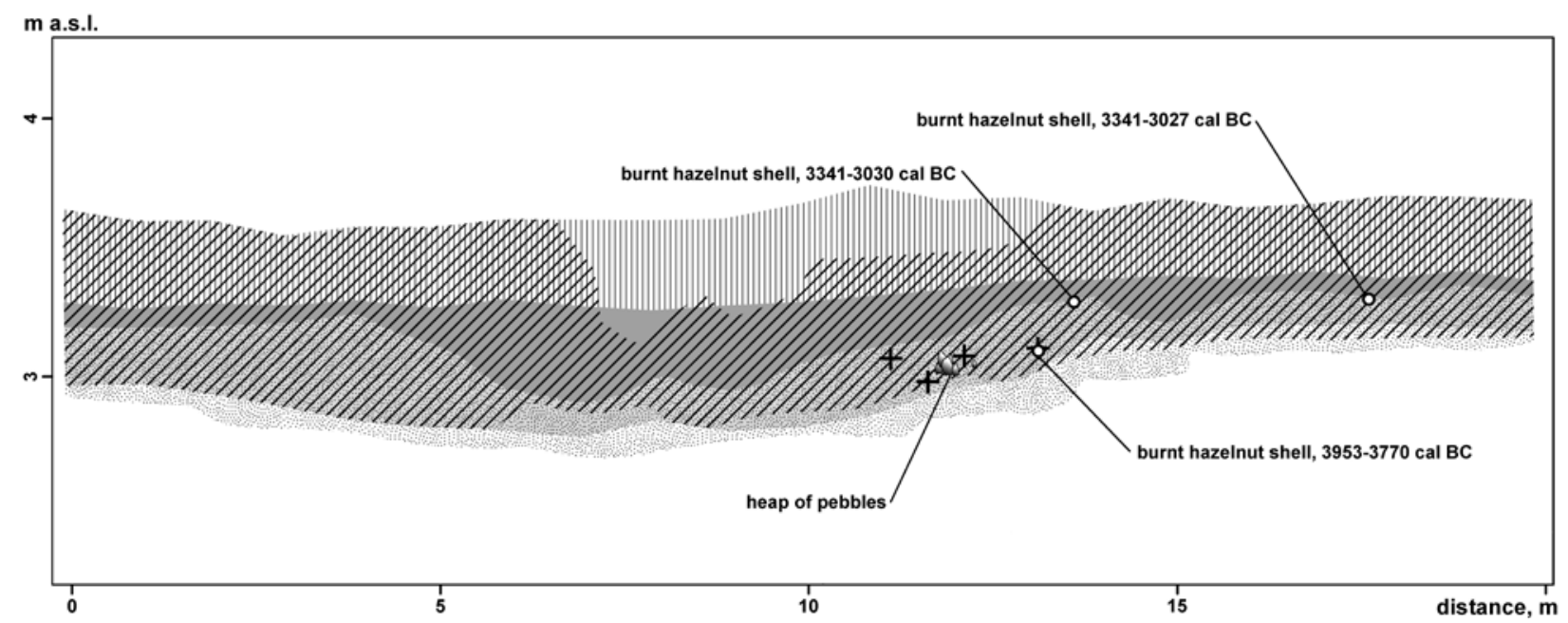

Fig. 7. Stratigraphic profile of the western wall of trench No 2 exaggerated by a factor of 3.5 with flint microliths (crosses) and radiocarbon dates (circles) marked. Lithologic symbols are explained in Figure 6. Drawing by G. Piličiauskas.

within the bottom part of the cultural layer and could indicate the original surface during prehistoric occupation (Fig. 7). The upper part of the cultural layer has most likely formed after the settlement was abandoned and involved natural post-depositional processes, such as peat deposition, frost action, mole burrowing, and ploughing.
Mapping the finds of various types, including pottery fragments, flints, other lithics and bones, revealed the same two-part structure of the site. Finds were concentrated on the two elevated areas in the northern and southern areas of the site that were separated by a slight depression, where only a few artefacts were found (Fig. 9). Radiocarbon 


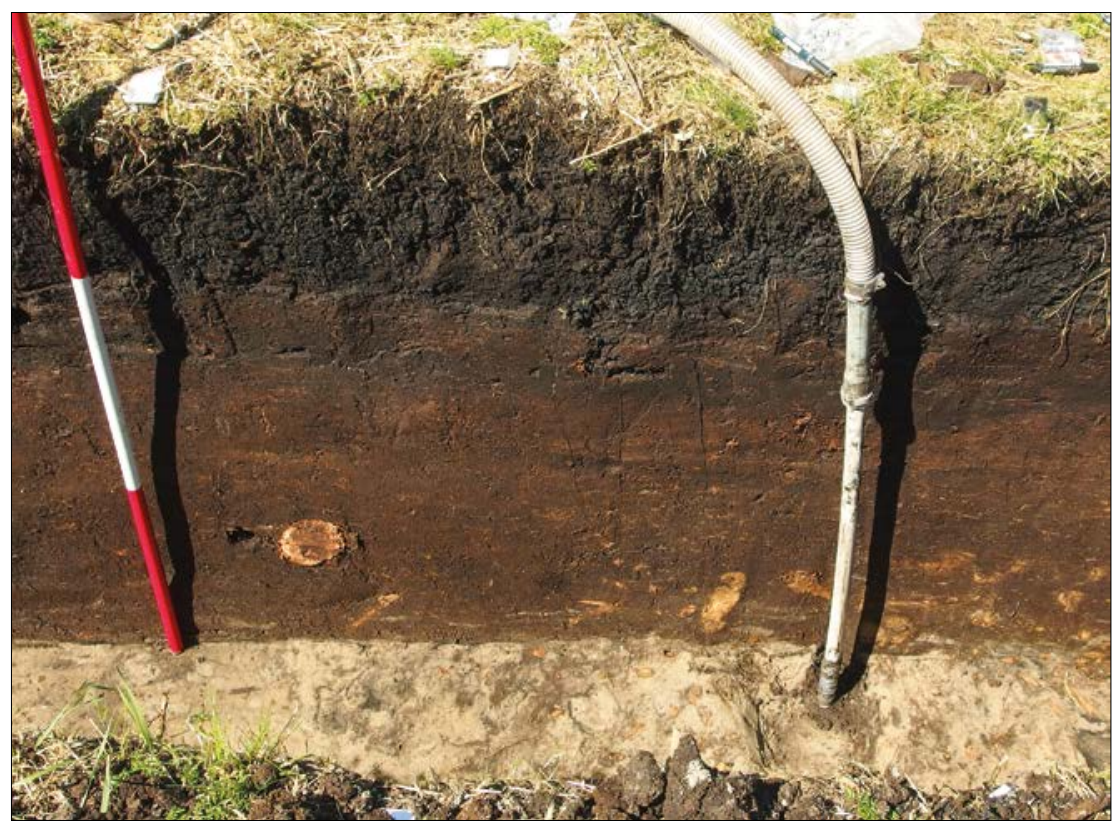

Fig. 8. Example of the stratigraphy in the lower part of the site. Photo by G. Piličiauskas.

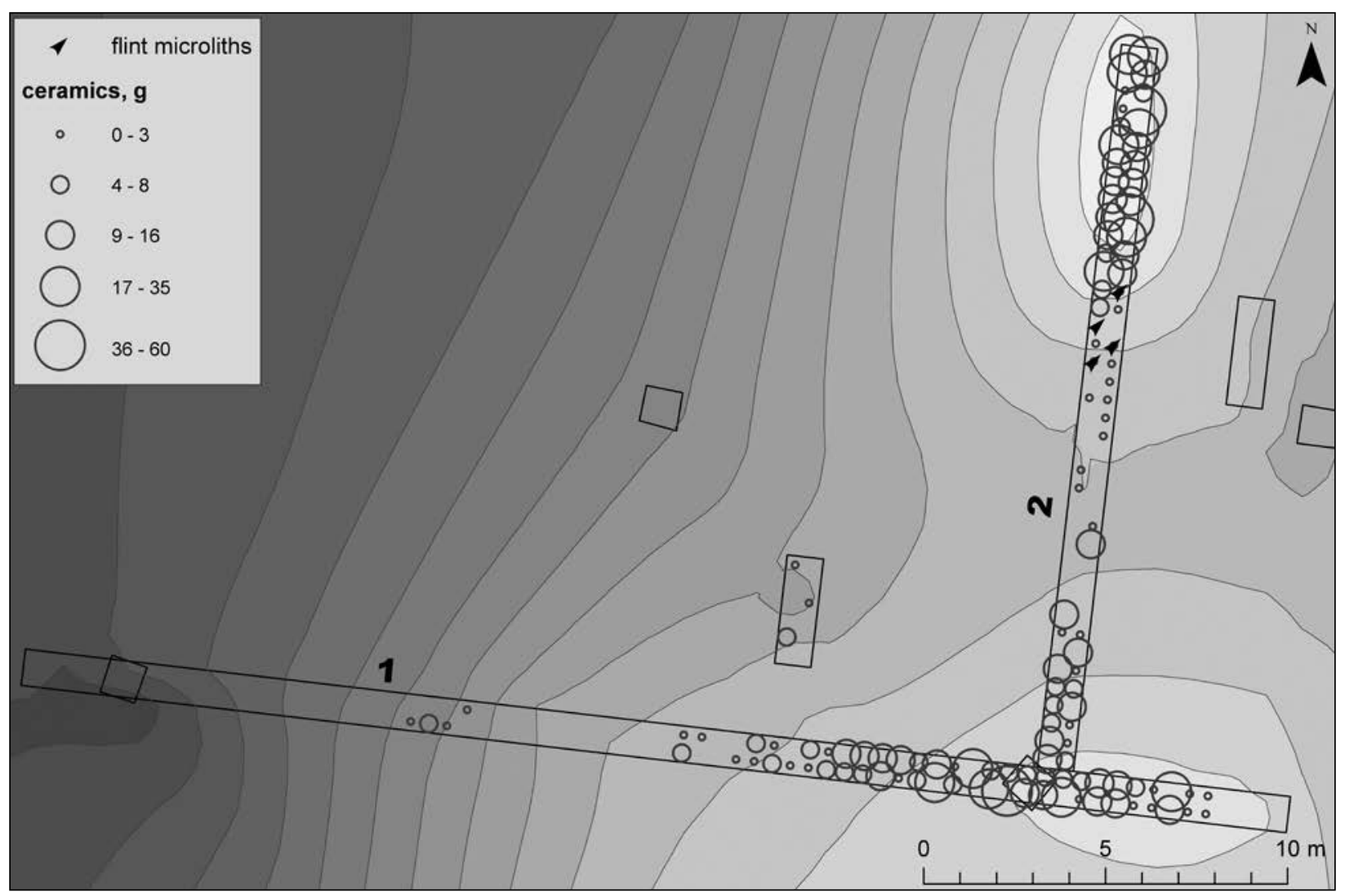

Fig. 9. Distribution of pottery (grams per $0.25 \mathrm{~m}^{2}$ ) and flint microliths that are plotted onto the shaded topography of marine sand. Flints, other lithics, amber, burnt and unburnt bones are distributed in a similar way as pottery into two distinct concentration areas. Drawing by G. Piličiauskas and L. Gaižauskas. 
dates and the similar character of finds at both the northern and southern parts of the site confirm that there is no chronological difference between materials from these two parts and that the time gap between their use is too small to be attested through artefact typology or radiocarbon dating (see further chapters).

\section{Preservation of the cultural layer}

An Adwa AD $111 \mathrm{pH}$ meter with the electrode A1230B was used to measure the alkalinity/acidity of the archaeological layer. The $\mathrm{pH}$ varied from 5.6 to 6.6 , although the highest values were recorded at lower depths and wetter places. These results indicate a slightly acidic environment that was favourable for the preservation of wood and bones (Retallack 1984). However, finds of both types were not well preserved. This may be due to microbiological activity that was stimulated after the dramatic drainage of the areas close to Šventoji 43 during the second part of the $20^{\text {th }}$ century. Today, the largest part of archaeological layer at Šventoji 43 is becoming drier every summer, which has consequences for the preservation of finds that are not yet excavated at the site. The examples from other Šventoji sites with similar ground water regimes has shown that there are not many years left until the remaining archaeological bones at Šventoji 43 are completely decayed. In 1970 and 1971, only a couple of years after melioration took place, both Šventoji 6 and 23 contained plenty of wooden and bone artefacts (Rimantiene 2005). However, in the subsequent 30-40 years following the excavation of the site, the remaining organic finds have been lost to decay (Piličiauskas 2016). It is likely that the same scenario will occur at Šventoji 43, which avoided direct melioration, but had the ground water level dramatically lowered due to the drainage of the adjacent territories. It should be also noted that even today bones are poorly preserved at Šventoji 43 . That was further attested by the C and
$\mathrm{N}$ stable isotope analysis that was conducted on the collagen of animal and fish bones and teeth. Eight samples of 23 examined yielded too little collagen for measurements, while an additional 3 samples fell outside of the acceptable range of $\mathrm{C}: \mathrm{N}$ ratios of 2.9-3.6, which can also be a sign of poor bone preservation (DeNiro 1985).

\section{Plant macroremains and diatoms}

At Šventoji 43 waterlogged plant remains survived only in the deepest and westernmost part of the cultural layer, below the water table. Five samples of peat (M1-M5), each $20 \times 20 \times 5 \mathrm{~mm}$ in size, were taken (Fig. 6). Macrobotanical analysis was performed by D. Kisieliene at the Quaternary Research Laboratory of the Nature Research Centre in Vilnius. The organic macroremains were extracted from sediment samples ( 21 in volume) by wet sieving through a screen with a mesh size of $200 \mu \mathrm{m}$. The dried material was sorted using a stereomicroscope at 10-120 X magnification, and plant macrofossils were identified using atlases of Grigas (1986), Cappers et al. (2006), Berggren (1969; 1981) and a reference collection of modern plants. Results of macrobotanical analysis are presented in table 1.

Sample M5 was taken from the peat interlayer embedded within a layer of fine and medium sand at a depth of $1.41 \mathrm{~m}$. There were no archaeological finds in this horizon. Only small fragments of natural amber were present. The most common identified plant remains belonged to dryland grasses (Table 1). Among them was Carex arenaria, which grows on sand dunes. Carex elongate prefers wetter habitats, but cannot tolerate constant flooding. Waterlogged hazelnut (Corylus avellana) shells were also present. Judging from the lithology, small amber fragments and plant taxa from different environments, it may be suggested that the thin peat layers that were found within the sand below archaeological horizon were formed from the redeposited dryland soils during 


\begin{tabular}{|c|c|c|c|c|c|c|}
\hline & Sample ID & M1 & M2 & M3 & M4 & M5 \\
\hline & Depth m & 0.49 & 1.03 & 1.22 & 1.27 & 1.41 \\
\hline & m a.s.l. & 2.41 & 2.22 & 1.93 & 1.88 & 1.73 \\
\hline \multirow{3}{*}{ 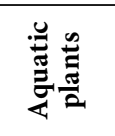 } & Potamogeton cf.pectinatus & & & & 27 & \\
\hline & Ranunculus aquatilis & & & 1 & & \\
\hline & sum & $\mathbf{0}$ & $\mathbf{0}$ & 1 & 27 & 0 \\
\hline \multirow{5}{*}{ 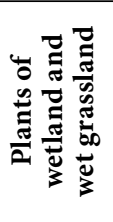 } & Schoenoplectus tabernamontani & & & 2 & 27 & 1 \\
\hline & Schoenoplectus lacustris & & & & 9 & \\
\hline & Carex elongata & & & & 3 & 1 \\
\hline & Carex sp. & & & & 1 & \\
\hline & sum & $\mathbf{0}$ & $\mathbf{0}$ & 2 & 40 & 2 \\
\hline \multirow{7}{*}{ 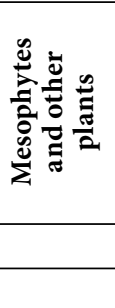 } & Carex arenaria & & & 6 & & 6 \\
\hline & Urtica dioica & & 18 & 4 & & 22 \\
\hline & Mentha sp. & & & 7 & 1 & 8 \\
\hline & Corylus avellana & & & 1 & & 1 \\
\hline & sum & $\mathbf{0}$ & 18 & 18 & 1 & 37 \\
\hline & charcoals & & & & $\mathbf{x}$ & $\mathbf{x}$ \\
\hline & total & $\mathbf{0}$ & 18 & 21 & 68 & 39 \\
\hline
\end{tabular}

Table 1. Results of plant macroremains analysis at Šventoji 43. Analysed by D. Kisielienè.

the Littorina Sea transgression, which occurred between 4227-3971 and 3944-3712 cal BC (Fig. 6).

Peat samples M4 and M3 were taken from archaeological horizon at depths of 1.27 and $1.22 \mathrm{~m}$ respectively (Table 1 ). Contrary to sample $\mathrm{M} 5$, aquatic and wetland plants were dominant in sample M4, including numerous seeds of Potamogeton cf. pectinatus. This plant tolerates both fresh and brackish water and usually grows at a depth of 1-3 m. Tiny pieces of natural amber may also suggest that peat at the bottom of the archaeological horizon formed under aquatic conditions, for instance in the littoral zone of an ancient lagoon. However, only $5 \mathrm{~cm}$ above sample M5, the peat from sample M3 was made up of a completely different set of plants where terrestrial taxa were dominant, including Mentha sp., Carex arenaria, and Urtica dioica. Natural amber was absent in this layer, while numerous tree roots and even several rooted stumps were still in situ and were uncovered (Fig. 6). This evidence points to the terrestrial origin of peat in this horizon. During its formation the coast of the lagoon was further West, and its water surface level must have been lower than $1.9 \mathrm{~m}$ a.s.l.
Samples M2 and M1 were taken from the peat overlying the archaeological horizon at the depths of 1.03 and $0.49 \mathrm{~m}$ respectively (Table 1 ). Visually, the peat layer that they were taken from appeared to be highly decomposed due to aeration. Perhaps unsurprisingly, very few plant macroremains were recovered. From M2 they all belonged to Urtica dioica. It may be assumed that dryland conditions continued even after the most intense period of occupation. From these analyses, we may see evidence that regression of the lagoon may have caused the abandonment of Šventoji 43 and resettling from 3-3.5 $\mathrm{m}$ a.s.l. (Šventoji 43) to $1.5-2 \mathrm{~m}$ a.s.l. (Šventoji 23, 26 , and 28) sites in order to follow the retreating coastline (Piličiauskas 2016).

Six soil samples, each of $20 \mathrm{ml}$, were taken from the archaeological horizon at various depths for diatom analysis. However, neither diatoms nor their fragments were found. 


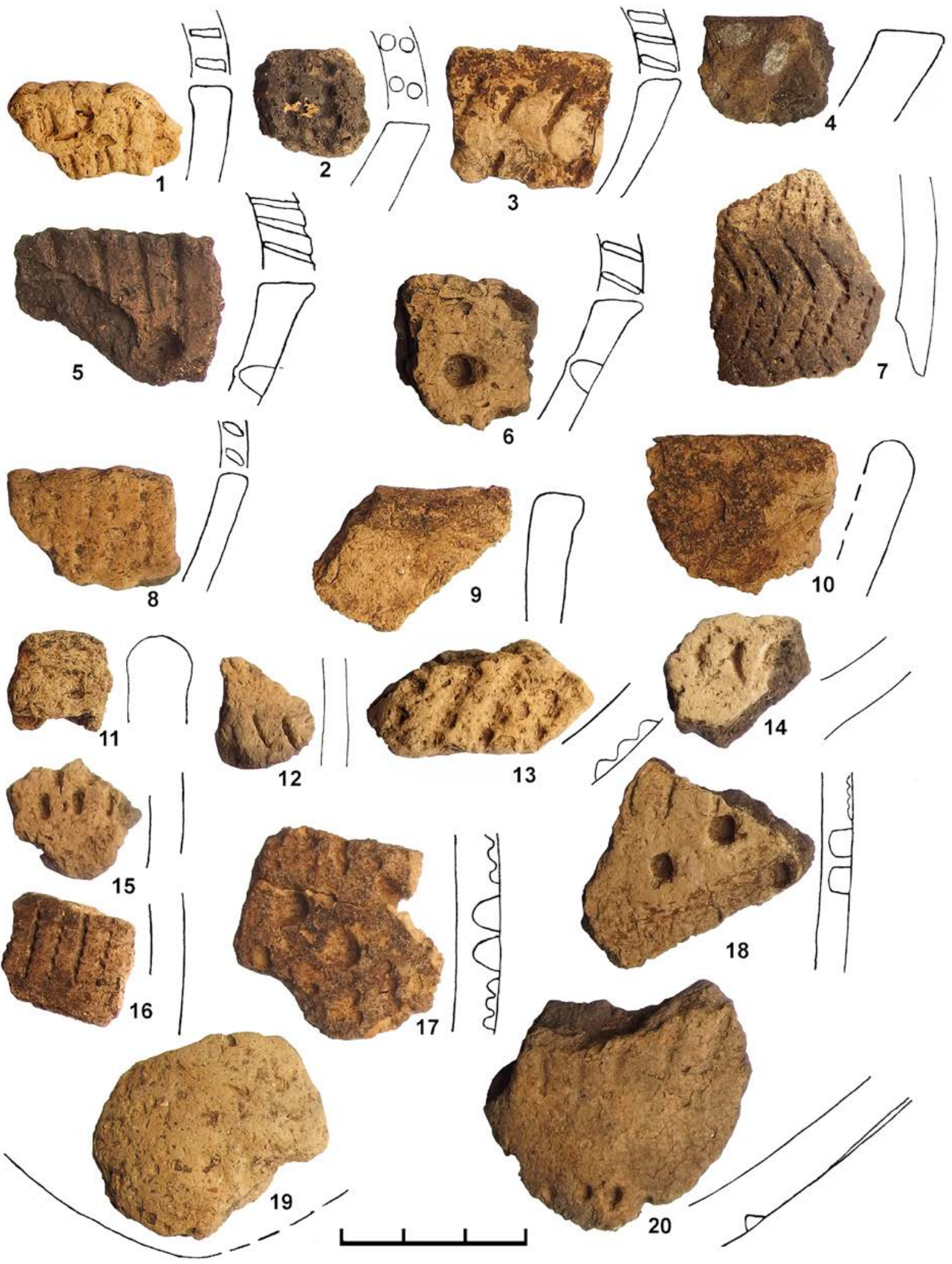

Fig. 10. Comb Ware pottery from Šventoji 43. Drawing by G. Piličiauskas. 


\section{Pottery}

In total 25,826 (ca. $1 \mathrm{~kg}$ ) of pottery fragments were collected at Šventoji 43. Pottery was highly fragile, fragmented, and small. The extreme brittleness of pottery at Šventoji 43 may be attributed to the postdepositional environment or perhaps to the low firing quality and properties of the pottery paste, as the potsherds of all other types at all other Šventoji sites were much better preserved even in the dry dwelling zones. From very small pottery fragments found at Šventoji 43, it may be argued that vessels had round bottoms and $10-30 \mathrm{~cm}$ wide mouths. The minimal number of vessels was 28 in total. Their fabric is porous, mostly tempered with crushed shells, which can be recognised by characteristic platy voids left after the shell decayed, and possibly plant or animal hair temper was added as well. Vessel walls, when compared with those of the Porous Ware at Šventoji 4 , were thinner and about $4-8 \mathrm{~mm}$ thick. They were built from coils using the $\mathrm{N}$-type junction. Surfaces were usually smoothed and, only occasionally, signs of striation with a comb like instrument were preserved on the inside of vessels. Rims were straight and mostly flat, slanting inwards and decorated. This differs from the later Porous Ware found at other Šventoji sites, where S-profiled or inside-protruding rims are very common (Rimantienè 2005). Judging by the proportion of decorated fragments in the whole assemblage, the majority of vessels were decorated and ornaments always cover almost all of the exterior surface from the edge to the bottom. This is quite different from the later Subneolithic pottery known from other Šventoji sites where undecorated vessels were widely used and where only the upper part of the vessel was usually decorated. At Šventoji 43 the most common decorative patterns were produced by combining deep and round pits with impressions made by a toothed stamp (Fig. 10:6, 17-18, 20). Sometimes comb impressions were also used without pits, such as the herring bone pattern (Fig. 10:7). The coarse-tooth impressions are found on larger vessels with thicker walls, while fine-tooth impressions are found on smaller vessels with thinner walls.

Rim forms and ornamentation of Šventoji 43 pottery puts it closer to the Typical Comb Ware of Latvia, Karelia, Estonia, and Finland (Янитс 1959a, табл. III-IV; 1959b, табл. VI-XV; Лозе 1988, табл. LI-LIII; Kulkova et al. 2016, fig. 7) rather than to the contemporaneous pottery at Daktariške 5 in West Lithuania (Piličiauskas 2018, fig. 21 and 22). The latter pottery was also tempered using organic agents, most commonly with crushed freshwater shell, while rim forms and the ornamentation of vessels differs significantly from Šventoji 43. Inward slanting rims are more prevalent at Daktariškè 5 and flat rims are rare. Also, pits together with toothed stamp ornamentation were never used at Daktariškè 5 for ornamentation, and there are few examples of ornaments arranged in patterns of horizontal bands. Knot and plait, oblong, column-like, and comb impressions and shallow pits were often arranged into patterns of interchanging horizontal and diagonal rows. Although organic temper was sometimes used in the production of Typical Comb Ware (e.g. Mökkönen, Nordqvist 2017), the use of organic temper is more common in the Late Comb Ware in Estonia as well as in the Porous Ware from Šventoji sites 2-4, 6, and 23, dated to ca. $3000 \mathrm{cal} \mathrm{BC}$ (Rimantienè 2005). Intriguingly, both organic (shell) and mineral temper was used for the production of Comb Ware vessels at the site of Priedaine in the Gulf of Riga, dated to 3700-3500 BC (Bērziņš et al. 2016).

\section{Amber}

Among the 2,198 pieces (756 g) of processed amber, only 18 artefacts were identified (Table 2). Large number of tiny amber flakes and chips as well as discarded preforms are proof that amber processing took place directly on the site. The most common type among the amber ornaments was V-perforated 
conical button (Table 3; Fig. 11:1, 3-4). V-perforated buttons were widely used in many Subneolithic, Neolithic, and Early Bonze Age cultures, such as Comb Ware, Porous Ware, Rzucewo and Bell Beaker. Hundreds of them were found at multiple Šventoji sites (Rimantienè 2005). Only a single V-perforated button had a quadrangular form. This type is much more common for the Neolithic rather than Subneolithic. However, most interesting is another type of the quadrangular button, which is present exclusively at Šventoji 43. It is a polished quadrangular button without the perforations, but with two notches made on the opposite edges instead, most likely for binding (Fig. 11:2). Only two such buttons were found at Šventoji 43 - one was completely intact and the other was a small fragment. We were unable to find analogies for the notched quadrangular buttons found at Šventoji 43. Perhaps this type of ornament was less practical when compared to perforated buttons and therefore did not spread widely.

\begin{tabular}{|c|c|c|c|c|c|}
\hline \multicolumn{6}{|c|}{ Amber } \\
\hline \multirow{3}{*}{ processed } & & finished & 10 & & \multirow{3}{*}{$\begin{array}{c}2198 \\
(756 \mathrm{~g})\end{array}$} \\
\hline & ornaments & $\begin{array}{l}\text { discarded } \\
\text { preforms }\end{array}$ & 8 & 18 & \\
\hline & waste & \multicolumn{3}{|c|}{2180} & \\
\hline \multicolumn{5}{|l|}{ natural } & 51 \\
\hline
\end{tabular}

Table 2. Amber finds at Šventoji 43.

\begin{tabular}{|l|l|c|}
\hline \multicolumn{1}{|c|}{ Type } & \multicolumn{1}{c|}{ Sub-type } & Number \\
\hline \multirow{3}{*}{ buttons } & conical V-perforated & 7 \\
\cline { 2 - 3 } & quadrangular V-perforated & 1 \\
\cline { 2 - 3 } & quadrangular holeless & 2 \\
\hline pendants & trapezoid & 4 \\
\hline beads & tubular & 2 \\
\hline rings & with angular cross-section & 1 \\
\hline preforms of unclear type & 1 \\
\hline In total & & 18 \\
\hline
\end{tabular}

Table 3. Types of amber ornaments found at Šventoji 43.

The other amber ornaments at Šventoji 43 are trapezoid pendants (Fig. 11:5-7) and preforms of tubular beads that had not yet been perforated longitudinally (Fig. 11:9-10). These ornaments, like V-perforated conical buttons, were widely used during the Subneolithic and Neolithic in the whole East Baltic and are not specific to any particular culture.

A single fragment of an amber ring was also present at Šventoji 43. It had a large central opening, an angular inside part of the cross-section, a notched outer edge, and several small perforations on the frontal surface (Fig. 11:8). Several amber rings are known from other Šventoji sites, but these are not of the same type as from Šventoji 43, since they have smaller central openings and undecorated edges (Rimantienè 2005, Abb. 107:2; 278:12; 335; 337:1; 349:10). An undecorated ring of a type similar to that of Šventoji 43 was present in Monciškès hoard which was collected in the vicinity of Šventoji 43 site at the end of $20^{\text {th }}$ century (Butrimas 2016, fig. 2). Further away from Šventoji, amber rings are known from Daktariškej 5 in Western Lithuania (Butrimas 2016, fig. 24:3; 39; 41-42) and from Lubāna Lake sites in East Latvia (Лозе 1988, табл. XLIII:3, LXIV). Very close analogies for the Šventoji 43 ring are known even from territories north of Latvia. Rings that have an angular cross-section with notched outer edges and sometimes perforated with small holes are known from Typical Comb Ware graves and settlements in Finland, Estonia, and Karelia. These rings were made from various materials, i.e. amber and various kinds of soft rocks (Янитс 1959a, табл. II:10; 1959b, рис. 61:4-7; Zhulnikov 2008, fig. 2; Kriiska 2015; Ahola 2017, fig. 9). These finds suggest that the idea, form, and the symbolic meaning of the stone/amber ring was first born not in amber bearing regions, like the Lithuanian coast, but in Finland or Karelia.

The amber assemblage from Šventoji 43 suggests that a third amber processing centre, in addition to Sārnate (Ванкина 1970) and Lubāna Lake (Лозе 1988) in Latvia, may have existed at Šventoji. These centres could have provided amber ornaments to the vast Comb Ware area that stretched east from the Baltic. Four standardised amber ornament types - pendants, 

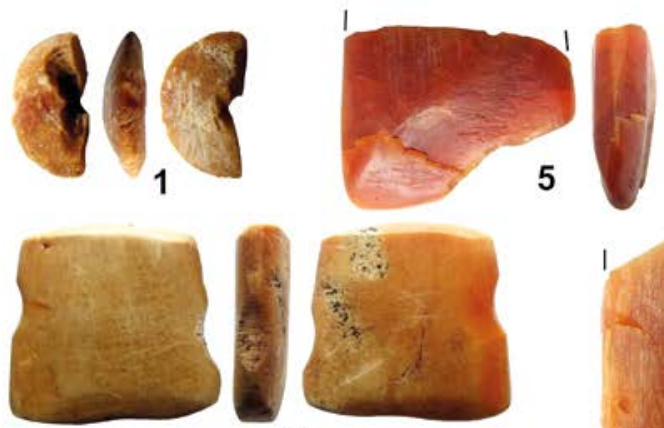

2
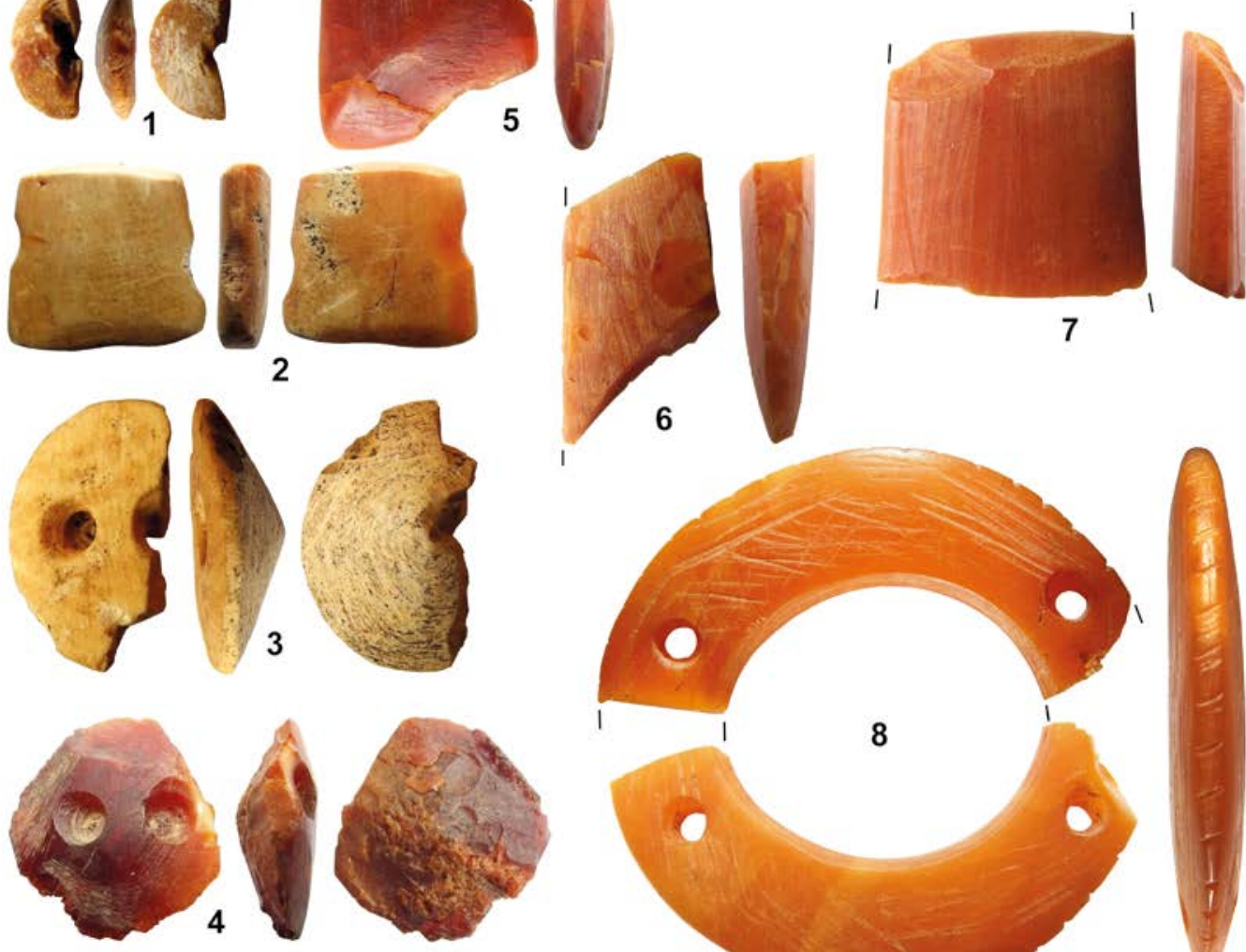

7
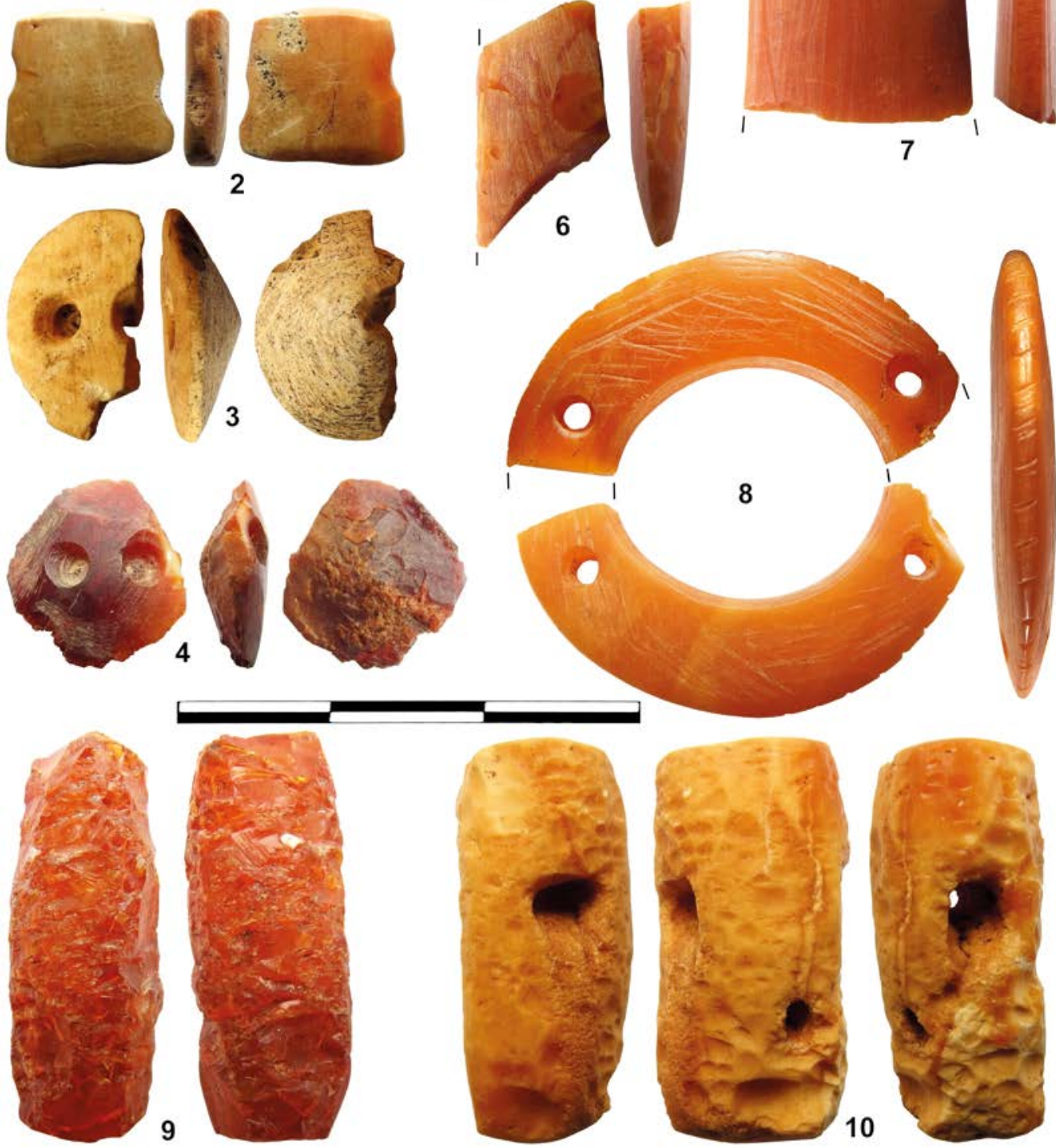

Fig. 11. Amber ornaments and their preforms found at Šventoji 43: conical V-perforated buttons (1 and 3-4), quadrangular notched button (2), trapezoid pendants (5-7), ring (8), and tubular beads (9-10). Photo by G. Piličiauskas.

V-perforated circular buttons, tubular beads, and rings - were produced at all three places. At Sārnate, tubular beads, rings and trapezoidal pendants were particularly characteristic of Comb Ware dwelling 3, while $\mathrm{V}$-perforated buttons were mostly found in later dwellings containing Early Sārnate Ware
(Bērziņš 2008). However, at Lubāna settlements, perforated buttons were commonly found in layers with Comb Ware, while the production and use of tubular beads was not restricted to this culture (Лозе 1988). Therefore, it seems that amber rings have the strongest association with Comb Ware, while 
other ornaments were also widely used during later periods, including Late Subneolithic, Neolithic and even the Early Bronze Age.

\section{Flints}

1,939 pieces of flint debitage and tools totalling $1.7 \mathrm{~kg}$ in weight were collected at Šventoji 43 (Table 4). This number is $5-10$ times higher when compared to of the sites of Šventoji 26 and 23, where excavated areas were even larger than at Šventoji 43 (Rimantienè 2005). However, this does not warrant the conclusion that the scale of flint processing was 5-10 times larger at Šventoji 43. This difference can be simply explained by different field excavation methods, where more precise recovery methods, namely wet sieving, were not used during the older excavations. Wet sieving enabled the discovery of hundreds of tiny flint flakes and chips at Šventoji 43 in 2014.

Local flint pebbles found on the Baltic Sea beaches were used at the site. They are small and of varying quality, and are light grey or white matt, rarely transparent grey or spotted. Judging from their appearance, most of the used flint should be classified as Silurian erratic flint, which was eroded from Silurian sediments in Southern Estonia and transported to Northwestern Lithuania by the last glacier (Kriiska 2015). Nodules of transparent grey flint also were used at the site. It is Cretaceous erratic (or Baltic) flint, which is also present on the Lithuanian coast in the form of beach pebbles, although it is less numerous when compared to the aforementioned Silurian flint.

Small flake fragments and chunks were dominant in the flint assemblage. Flakes usually did not exceed $0.5-2 \mathrm{~cm}$. These finds demonstrate that flint knapping undoubtedly took place at the site. Flint flakes with opposite scars and crushed and absent platforms, sandstone plates/anvils with battered areas as well as one bipolar flint core found (Fig. 12:17) indicate that bipolar percussion was used as a principal technique to process the small flint pebbles that were usually of poor quality. However, it was not the only knapping technique used. Direct hard hammer percussion was also in use, as is evident from flakes or even irregular blades having substantial remnants of the flaking platforms preserved. However, platform cores did not survive, as they were probably utilised by bipolar reduction after they became too small for freehand knapping.

\begin{tabular}{|l|l|l|r|}
\hline \multirow{2}{*}{ retouched tools } & on irregular blades & 7 & \multirow{2}{*}{32} \\
\cline { 2 - 3 } & on flakes & 25 & 1 \\
\hline cores & bipolar & 6 \\
\hline blades & irregular & 1,900 \\
\hline flakes and debris & & \multicolumn{2}{|c}{$1,939(1.7 \mathrm{~kg})$} \\
\hline In total & \multicolumn{2}{|c}{} \\
\hline
\end{tabular}

Table 4. Flint tools and processing waste at Šventoji 43.

Many flakes and blades may have been used as tools without retouching, as is attested by the usewear traces visible with the naked eye on some of the artefacts (e.g. Fig. 12:10). Only 32 flint artefacts were ascribed to the category of formal (or retouched) tools and that makes up only $1.6 \%$ of the whole assemblage. Despite the dominance of bipolar splinters in the assemblage, platform flakes and irregular blades were the most commonly selected preforms for retouching. The fraction of irregular blades among the retouched tools (21.9\%) is much higher than within the whole assemblage $(0.3 \%)$. Among tools, side and end scrapers made on flakes of various forms are dominant (Fig. 12:8-9, 11-16). Large cutting tools such as axes are absent. The most intriguing finds are 4 microliths made of irregular blades, classified as a trapeze, triangle, and truncated bladelet (Fig. 12:12, 4-5). These are different from the Mesolithic forms since they do not demonstrate any signs of microburin technique. No microburins were found at Šventoji 43 either. All 4 microliths were found within 2 meters apart from each other at the lower horizon of the archaeological layer with Comb Ware 


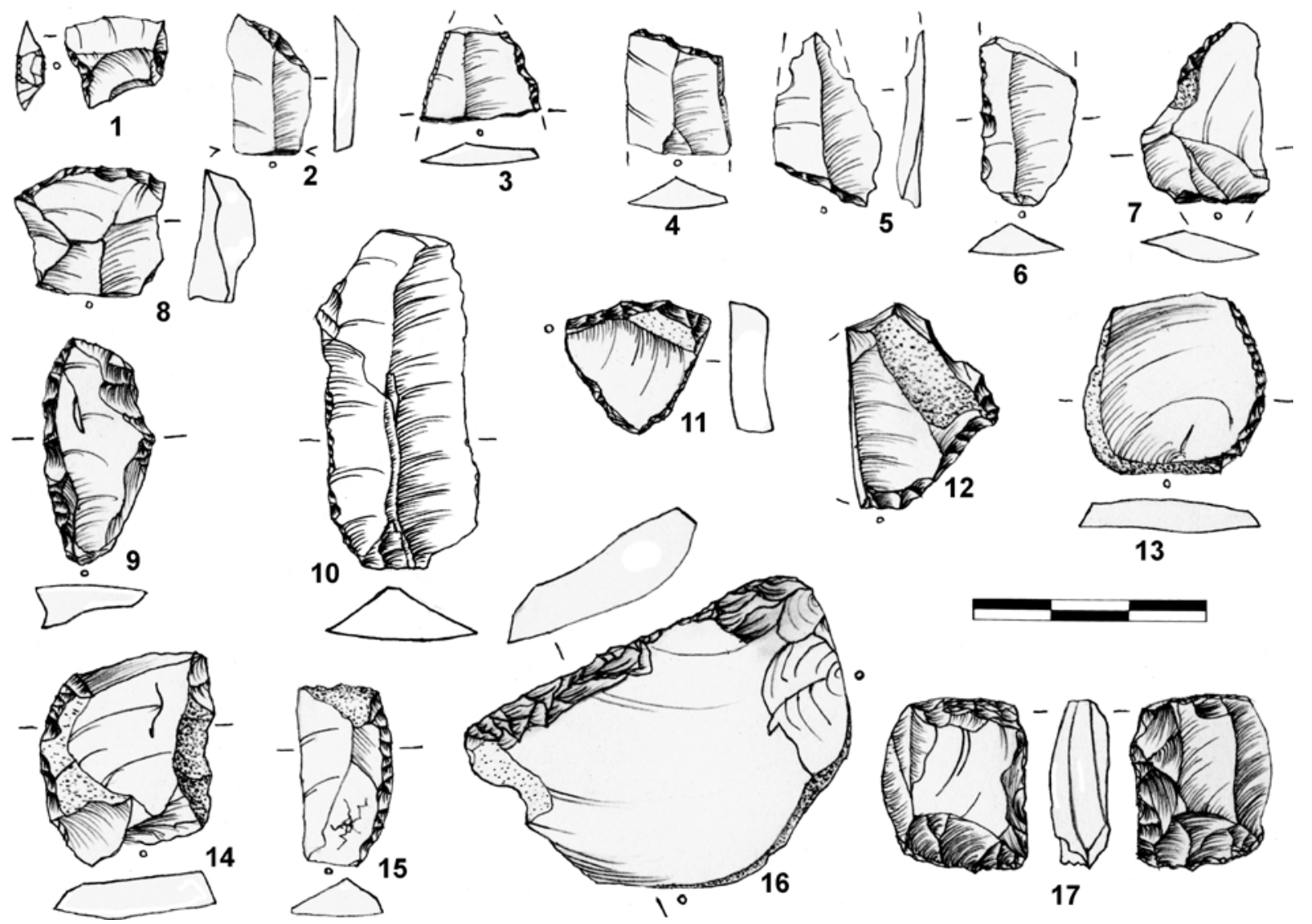

Fig. 12. Flint artefacts from Šventoji 43. Drawing by G. Piličiauskas.

(Fig. 7). It is highly unlikely that they are from the preceramic phase, for which there is no other evidence at the site. Their concentration in a single small area may indicate a short occupation period.

Flint microliths of various forms including microburins are known only from few other sites at Šventoji - Būtingè 1 and Šventoji 40. Both of these, however, are multi-period, unstratified sandy sites, situated on Šventoji River banks, which are $1.5 \mathrm{~m}$ higher than the lagoonal coasts. Furthermore, both sites were certainly occupied during the Late Mesolithic (ca. 6000 cal BC) and both lack Subneolithic pottery finds (Rimantienè 2005, Abb. 383; Piličiauskas 2018, pp. 101-110). Flint microliths in the form of trapeze were widely used during the early Subneolithic (or ceramic Mesolithic) stages in Polish Pomerania and Southern Scandinavia in the $5^{\text {th }}$ millennium cal BC
(Larsson 1990; Sobkowiak-Tabaka 2015). However, they are completely absent at Comb Ware sites throughout the East Baltic with the single exception of Šventoji 43. Rhomboid or leaf-like bifacial points instead of microliths were widely used there (Янитс 1959b, рис. 16-18; Янитс 1959а, табл. 1; Ванкина 1970; Лозе 1988, табл. XIX, LXI; Kriiska 2015, p. 110). Bifacial rhomboid or oval points were also in use during later periods and are found at Šventoji sites dated to 3200-2700 cal BC (Rimantienè 2005, Abb. $146: 3,270: 17,357: 10)$, although they are usually found together with triangular points. However, at Šventoji 43 all forms of bifacial points are absent.

Microlithic tools found at Šventoji 43 site may provide evidence for the local Mesolithic origin of the community that produced pottery classified as Comb Ware. A very similar flint industry, which was 
based on the exploitation of local erratic flint of small dimensions and incorporated platform and bipolar stages of core reduction and lacked large cutting flint tools, e.g. axes, was attested in the Mesolithic of Polish Pomerania (Wąs 2016). The state of research of the Late Mesolithic flint industry on the Lithuanian coastal is still very poor, but it seems that Mesolithic flint assemblages differ from that of Šventoji 43, as they contain regular blades, signs of microburin technique used, and numerous imported Cretaceous flints (Piličiauskas 2016).

\section{Other lithics}

Almost 2,000 ( 2.2 kg) pieces of non-siliceous rocks were collected at Šventoji 43. Most of them $(\sim 1,800)$ were intact or fragmented sea beach pebbles, without visible traces of processing (Table 5). However, even those had to be brought to the site by people, since the fine Littorina Sea sand, on which the settlement was situated, is devoid of boulders or pebbles.

\begin{tabular}{|c|c|c|c|c|}
\hline & flakes & $\begin{array}{c}\text { flaked } \\
\text { pebbles }\end{array}$ & tools & $\begin{array}{c}\text { unworked } \\
\text { pebbles } \\
\text { and crumbles }\end{array}$ \\
\hline sandstone & 100 & 23 & 6 & \multirow{14}{*}{$\sim 1,800$} \\
\hline granite & 10 & 7 & 1 & \\
\hline amphibolite & 13 & 1 & & \\
\hline diabase & 4 & & 3 & \\
\hline quartzite & 5 & & 1 & \\
\hline basalt & 2 & & & \\
\hline quartz & 4 & 1 & & \\
\hline $\begin{array}{l}\text { plagioclase porp- } \\
\text { hyry }\end{array}$ & 1 & 1 & 2 & \\
\hline metadiabase & 2 & & & \\
\hline limestone & 2 & & & \\
\hline granite-gneiss & 1 & & & \\
\hline slate or metatuff & & & 1 & \\
\hline unidentified & 8 & 1 & $3 ?$ & \\
\hline Sum: & 152 & 34 & 14 & \\
\hline In total: & \multicolumn{4}{|c|}{$\sim 2,000(\sim 22 \mathrm{~kg})$} \\
\hline
\end{tabular}

Table 5. Finds of non-siliceous rocks at Šventoji 43. Rocks were identified by AK with the aid of geologist G. Motuza-Matuzevičius.
Rock types of about 200 lithics with processing traces were determined at Šventoji 43 (Table 5). Among them several varieties of sandstone clearly predominate the assemblage. Other rocks, such as granite, amphibolite, diabase, quartzite, porphyry, and quartz, were of much lower importance (Fig. 13 and 14). Most of the identified rocks are locally available and can be found on the beach or in moraines with a single exception: an adze made of a variety of greenish grey slate or metatuff with black dots (Fig. 14:3). This raw material could be sourced to Finland. It is important to note that slate or metatuff tools are much more numerous and clearly dominate in the category of polished stone artefacts at later Šventoji sites (e.g. Šventoji 6; Fig. 15). They are primarily recognised as imports from Karelia or Estonia (Rimantiene 1996; 2005). Slate is present on the Lithuanian coast as beach pebbles, but they are very few and too small to be used for local production of polished tools on a significant scale.

Unworked pebbles and fragments of sandstone plates may have been used as net sinkers. From other Šventoji sites we know that small unworked pebbles were wrapped into birch bark prior to being attached to a net, while larger ones were attached to the net by lime bast ropes or threads (Rimantienè 2005, Abb. 168 and 266). However, side or endnotched pebble sinkers, which are characteristic for other Šventoji sites (e.g. Rimantienè 2005, Abb. 266), are completely missing at Šventoji 43. Here, large sandstone plates were intentionally fragmented into many angular pieces, which were perhaps used as net sinkers without any additional processing or with some flaking at the edges (Fig. 13:1 and 2). However, this is only speculative, as none of these were found with the preserved binding like in other Šventoji sites where the cultural layer extends into lagoonal gyttja.

Some stone tools were classified as hammers, anvils, or combined hammers/anvils used in flint knapping by bipolar percussion (Fig. 13:3-7). There 

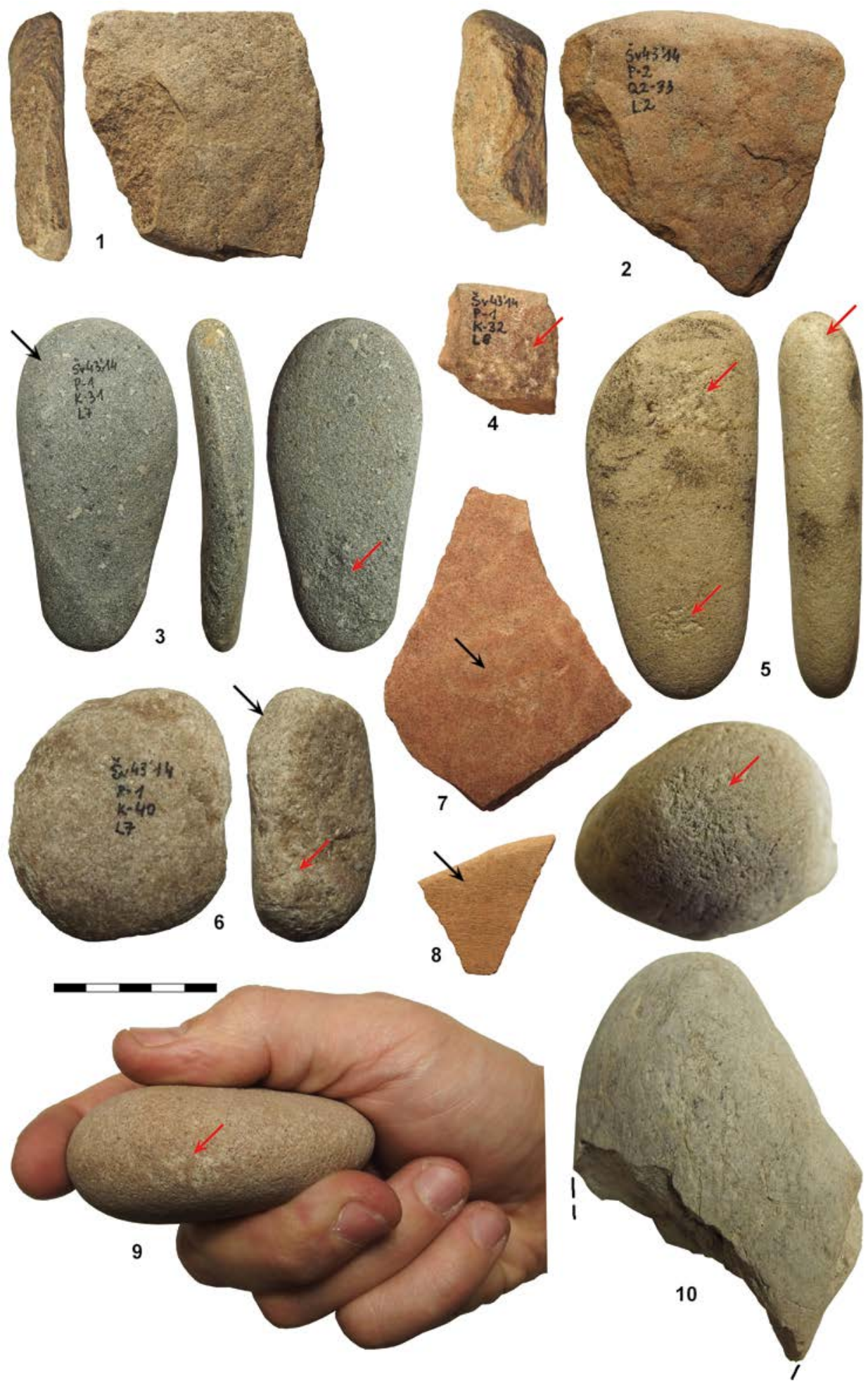

Fig. 13. Artefacts made on non-siliceous rocks from Šventoji 43: sandstone net sinkers (?) (1-2), meta-porphyry anvil/sharpener (3), fragment of a sandstone anvil (4), sandstone hammer/anvil (5), quartzite hammer/sharpener (6), sandstone polishing plate (7), sandstone grinding plate (8), sandstone hammer (9) and quartzite hammer (10). Battered areas are indicated by red arrows, polished or ground by black. Photo by G. Piličiauskas. 

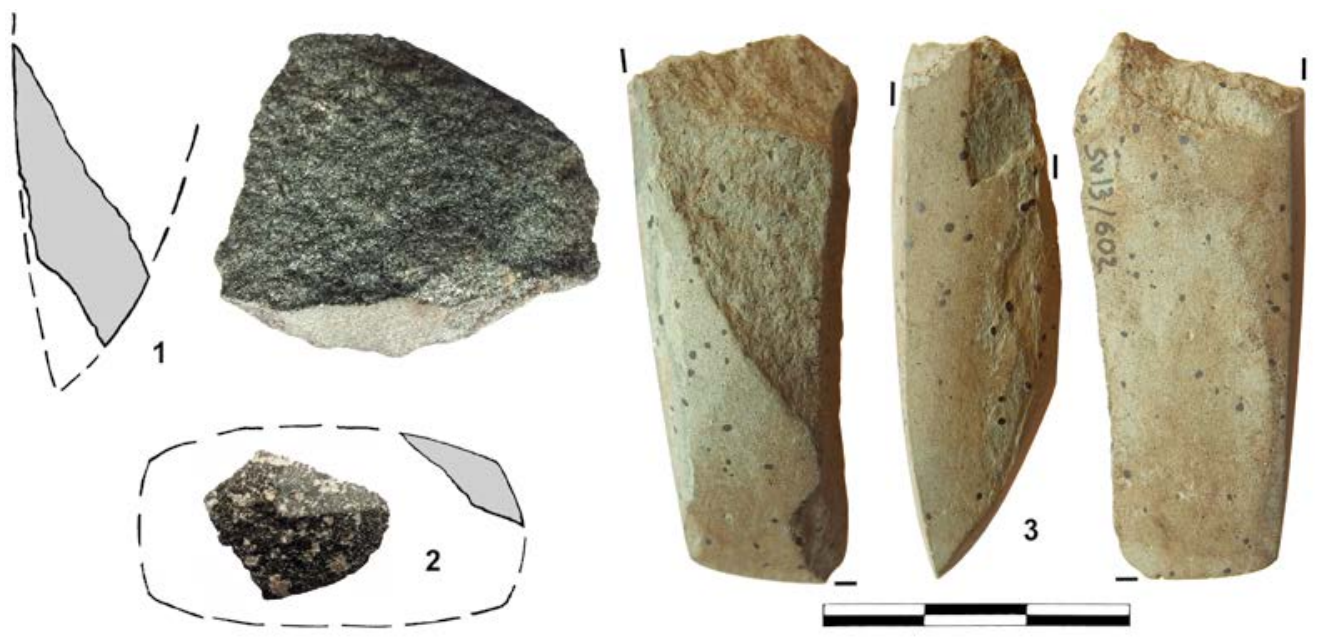

Fig. 14. Fragments of polished adzes (and axes?) made on various non-siliceous rocks found at Šventoji 43: diabase (1), porphyry (2), and slate (3). Photo by G. Piličiauskas.

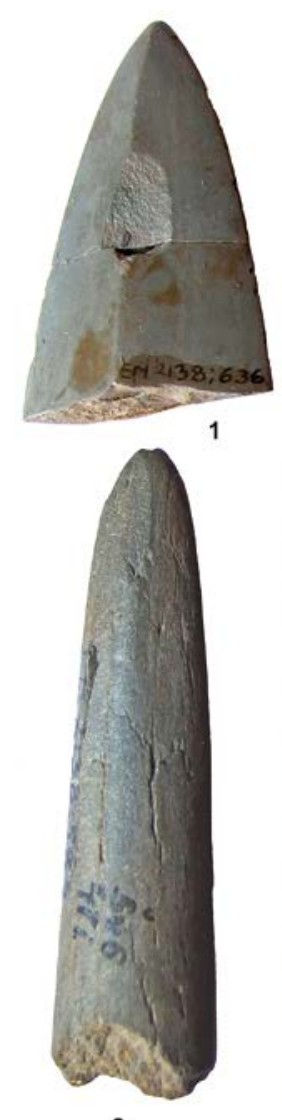

2
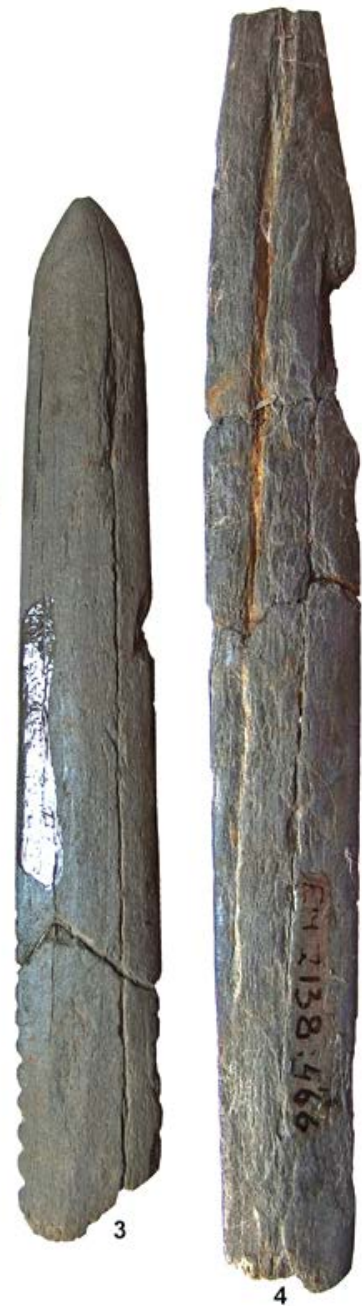
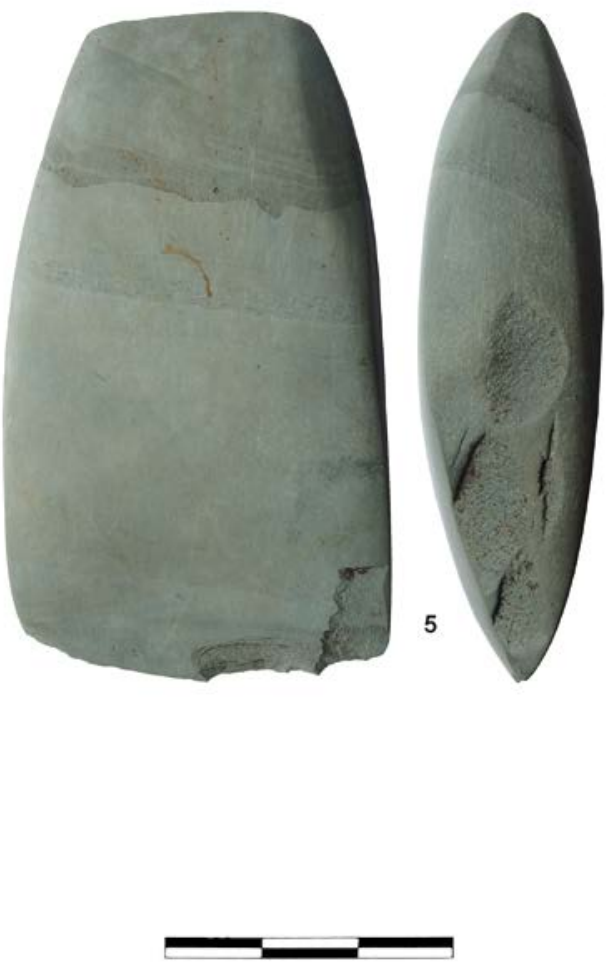

Fig. 15. Slate (2-4) and Onega metatuff (1 and 5) artefacts from Šventoji 6 and 26 sites. Photo by G. Piličiauskas. 
was neither a single form nor a single rock type preferred for this activity. Pebbles of various size, weight, and rock type were used. At least 3 types of hammers may be distinguished. Asymmetric flat sandstone and porphyry pebbles about $10 \mathrm{~cm}$ long were used as the lightest hammers/anvils (Fig. 13:3 and 5). Battered zones were observed on their edges and flat surfaces. Another type of hammer stone is represented by sandstone and quartzite pebbles more massive and therefore heavier, yet more comfortable to hold and grip (Fig. 13:6 and 9). They may have been used for both direct freehand percussion and bipolar knapping as is indicated by the battered areas at the edges. Finally, massive pebbles that
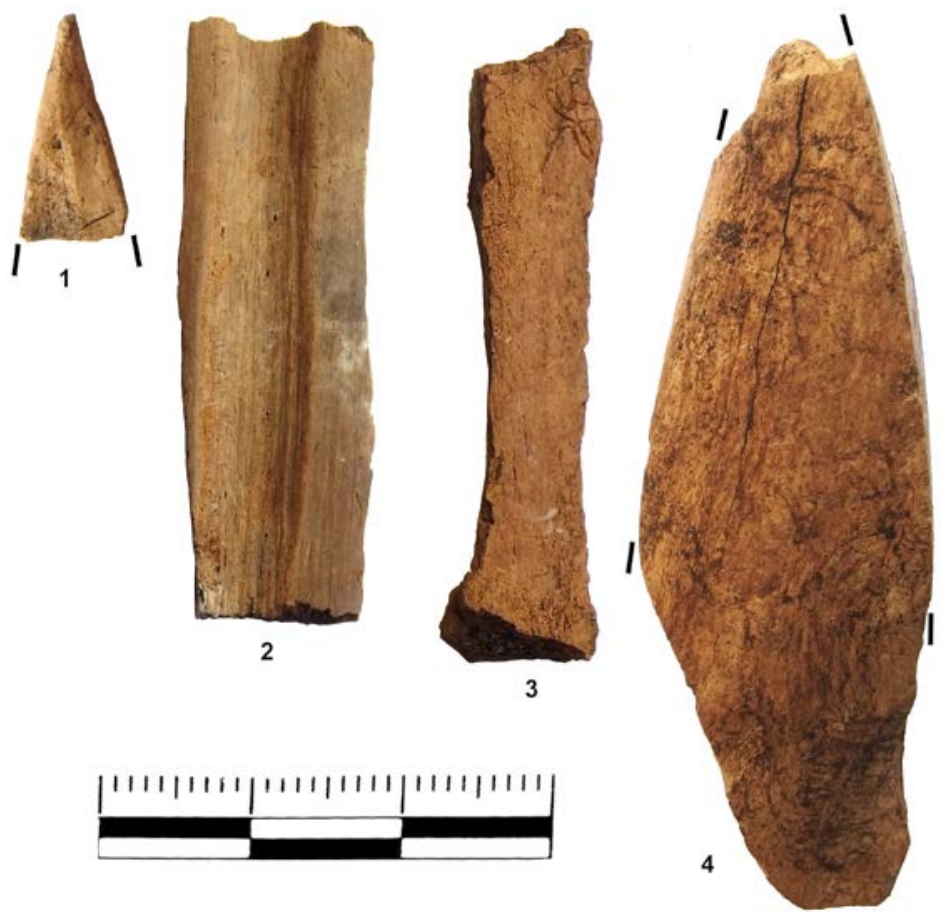
were more than $10 \mathrm{~cm}$ long were also in use, as can be seen from a fragment of a single quartzite tool (Fig. 13:10). Besides

Fig. 16. Fragments of bone tools from Šventoji 43. Photo by G. Piličiauskas. trapezoidal cross-section (Fig. 14:3), while the other 2 were made of diabase and porphyry and are too small to allow a reliable reconstruction (Fig. 14:1-2).

A heap of 9 granite pebbles was uncovered in trench 2 (Fig. 7). They were heavily disintegrated into crumbles by humic acids, of various sizes, $5-15 \mathrm{~cm}$ in diameter, and perhaps were used for another household activity rather than fishing.

\section{Bone and antler tools} rough single-direction striations are clearly visible (Fig. 13:8). The presence of fragments of stone adzes and bone tools suggests that various materials had to be ground or polished with the aid of sandstone plates. Grinding rocks of different hardness on the sandstone plates may result in different alteration of the plate surface.

Fragments of 3 polished adzes (and perhaps axes?) were also identified at Šventoji 43. The largest one that was possibly made of Kemijoki slate has a 


\begin{tabular}{|c|c|c|c|c|}
\hline No & date BP & cal BC/AD (95.4\%) & sample description & reference \\
\hline 1 & Poz-64686: $5240 \pm 50$ & $4230-3970 \mathrm{BC}$ & $\begin{array}{l}\text { 2014, trench } 1,1.35 \mathrm{~m} \text { depth, square K-81, waterlogged hazelnut } \\
\text { shell from black peat interlayer within fine sand below cultural } \\
\text { layer }\end{array}$ & this study \\
\hline 2 & Poz-64690: 5045 \pm 30 & $3950-3770 \mathrm{BC}$ & 2014, trench 2, level 6, square M2-34, charred hazelnut shell & this study \\
\hline 3 & Poz-66912: 5025 \pm 35 & $3940-3710 \mathrm{BC}$ & 2014, trench 2, charred wood No 1282 & this study \\
\hline 4 & Poz-64688: $4945 \pm 30$ & $3780-3655 \mathrm{BC}$ & 2014, trench 1, level 9, square K-46, charred hazelnut shell & this study \\
\hline 5 & Poz-64687: 4905 \pm 30 & $3760-3640 \mathrm{BC}$ & 2014, trench 1, level 7, square K-27, charred hazelnut shell & this study \\
\hline 6 & Poz-64689: $4480 \pm 30$ & $3340-3030 \mathrm{BC}$ & 2014, trench 2, level 4, square N2-34, charred hazelnut shell & this study \\
\hline 7 & Poz-66911: 4475 \pm 35 & $3340-3030 \mathrm{BC}$ & 2014, trench 2, level 4, square V2-33, charred hazelnut shell & this study \\
\hline 8 & Poz-61701: $95 \pm 30$ & $1682-1931 \mathrm{AD}$ & $\begin{array}{l}\text { 2013, test pit 203, } 0.4-0.6 \text { depth, cattle upper M1 tooth from } \\
\text { the lowermost part of plough zone }\end{array}$ & $\begin{array}{l}\text { Piličiauskas } \\
\text { et al. 2017b }\end{array}$ \\
\hline
\end{tabular}

Table 6. List of radiocarbon dates obtained for Šventoji 43.

\section{Chronology}

Eight radiocarbon dates were obtained for Šventoji 43 (Table 6). One of the dates was from a cattle tooth found in a test pit outside the main area of the site and appeared to be modern - Poz-61701: 95 \pm 30 BP. Another date (Poz-64686: 5240 \pm 50 BP) was yielded from a hazelnut shell found below the archaeological horizon. The remaining 6 dates were obtained from charred hazelnut shells and wood found in the archaeological horizon and thus should be related with onsite human activities. These 6 dates can be grouped into two phases, ca. 3900-3650 cal BC and 3300-3100 cal BC, with a definite gap in between them (Fig. 17). The pause in occupation was caused by the regression of the Littorina sea and Šventoji paleolagoon, which is indicated by the formation of the erosional channel at Šventoji 1-4 and 41 sites around $3500 \mathrm{cal} \mathrm{BC} \mathrm{(Piličiauskas} \mathrm{et} \mathrm{al.}$ 2015, fig. 12; Piličiauskas 2016). The coastline of the drained lagoon moved to the West and the Šventoji 43 appeared to be too far from the coast. However, at ca. $3200 \mathrm{cal} \mathrm{BC}$ the coastline moved to the previous level due to a transgression.

The older phase has 4 radiocarbon dates obtained from samples from various parts of the site at various depths, while the later phase has only 2 radiocarbon dates obtained for the upper part of the archaeological layer in trench 2 (Fig. 6 and 7). The $2^{\text {nd }}$ phase is synchronous with many other Subneolithic Šventoji sites, e.g. 2, 3, 4, 6, and 23, where Porous Ware was found (Piličiauskas 2016). However, Porous Ware, which is very well defined by numerous pottery finds at many Šventoji sites, is missing at Šventoji 43, even though two charred hazelnut shells were dated to that period. At Šventoji 43, the archaeological material stylistically and technologically looks homogenous in all parts of the archaeological layer. This leads us to the conclusion that the main occupation took place and the most of archaeological material was deposited during the $1^{\text {st }}$ phase, while only episodic human activities, which have not resulted in the accumulation of ceramic deposits, occurred during the $2^{\text {nd }}$ phase. Therefore, the Comb Ware culture occupation at Šventoji 43 should be assigned to the $1^{\text {st }}$ phase and dated to ca. 3900-3650 cal BC. The Comb Ware occupation may have lasted from 11 to 256 years with $95.4 \%$ probability (Fig. 18). The suggested dating of Šventoji 43 is compatible with the chronology of Typical Comb Ware in Finland and Estonia (4000-3400 cal BC; Nordqvist et al. 2012, Fig. 2). Organic-tempered Typical Comb Ware from this period is also known in Finland (Mökkönen, Nordqvist 2017). Similarly, in Estonia organic tempered Comb Ware is dated only to after 3750 cal BC (Sander, Kriiska 2018).

Since no Porous Ware older than $3200 \mathrm{cal} \mathrm{BC}$ is known in coastal Lithuania, Šventoji 43 confirms the 


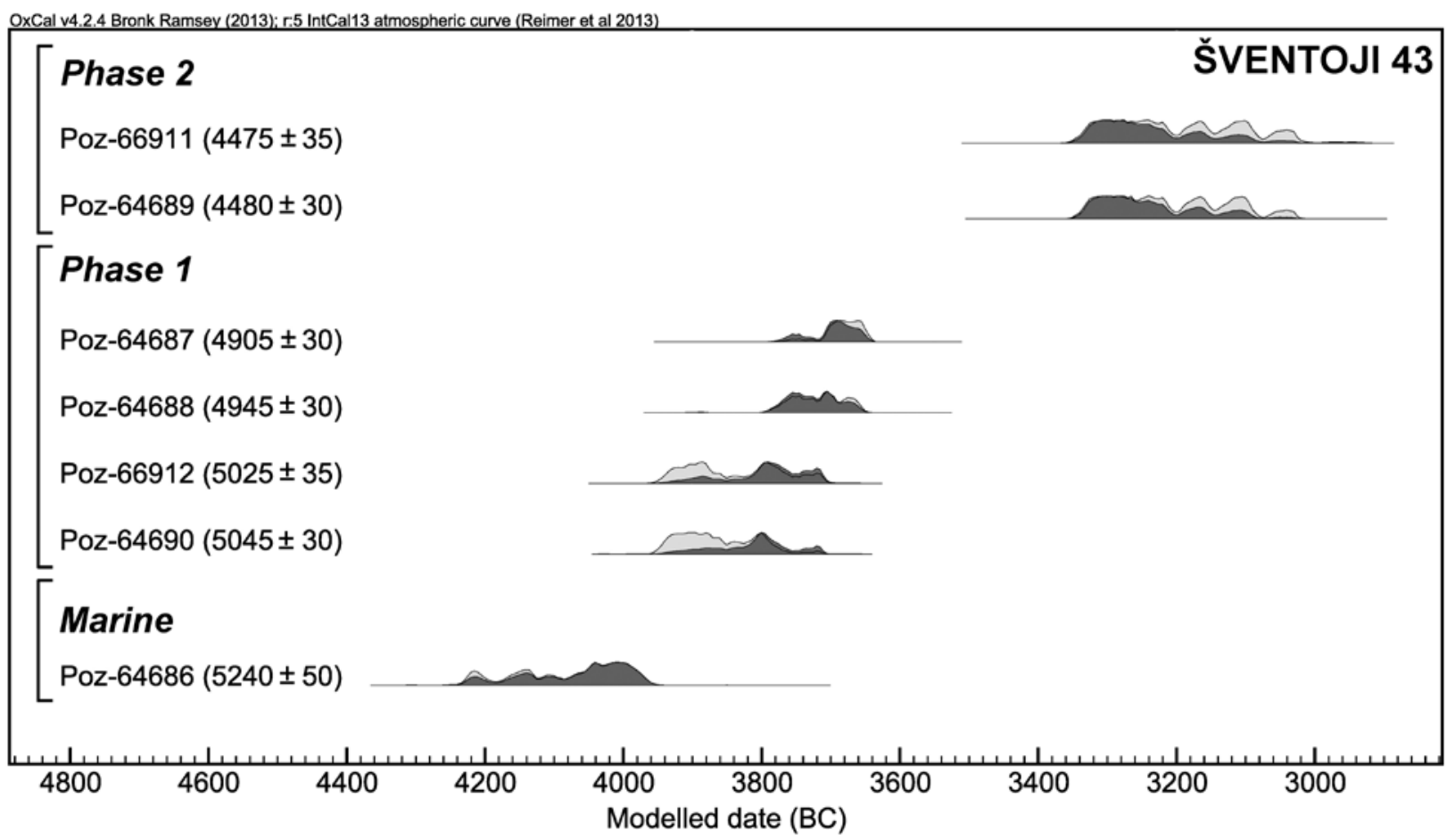

Fig. 17. Calibrated and modelled radiocarbon dates from Šventoji 43. Drawing by G. Piličiauskas.

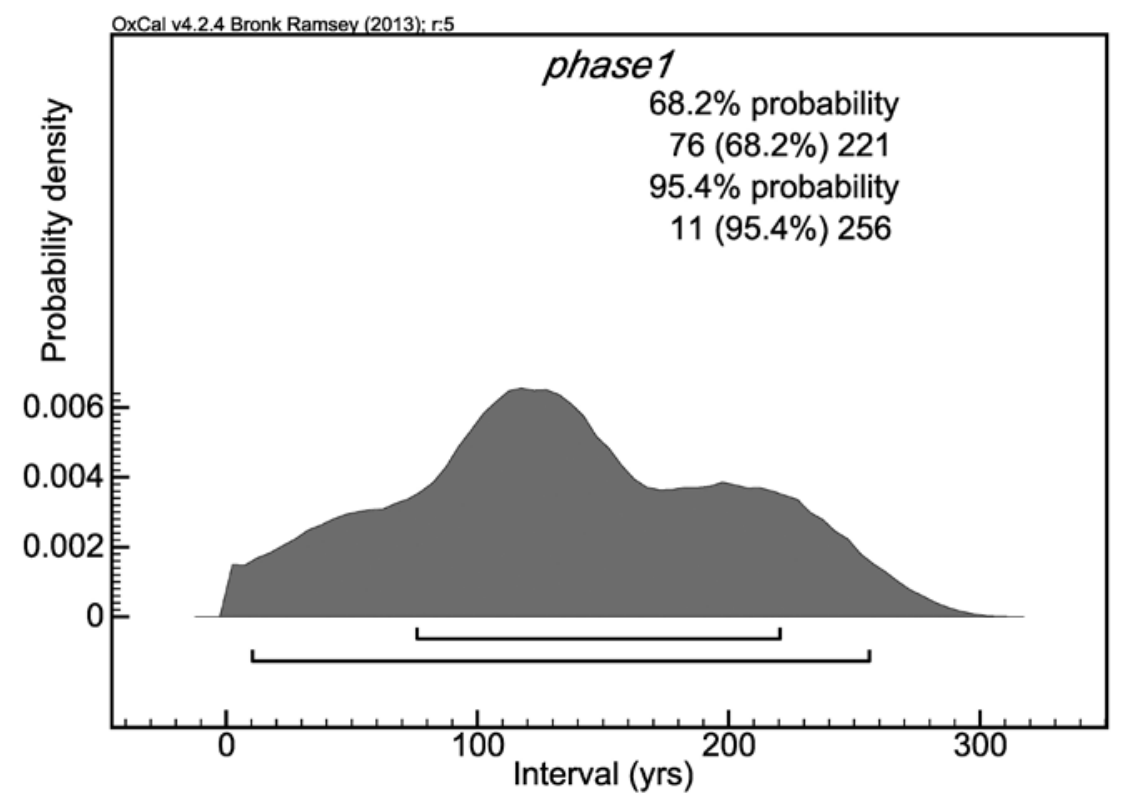

Fig. 18. Probability ranges of the $1^{\text {st }}$ phase at Šventoji 43. Drawing by G. Piličiauskas.

existence of a separate phase of Comb Ware within the local pottery sequence. It has also become clear that Comb Ware of Šventoji 43, as well as Comb-like
Ware of Šventoji 26, predates Porous Ware found at many other Šventoji sites. This is a new find, since the Comb-like Ware of Šventoji 26 was thought to 
be the youngest among the Subneolithic wares in Šventoji (Rimantienè 2005).

\section{Zooarchaeological data}

Unworked animal and fish bones were much more numerous than bone tools at Šventoji 43. Approximately 26,000 ( 10 kg) bone fragments were collected and about 17,000 (63\%) of them were burnt. 1447 bone fragments were identified to the species level and this accounts for $6 \%$ of the whole assemblage. Looking at the whole assemblage, it seems that mammal bone fragments strongly predominate, while fish and bird bones account for only 3 and $0.2 \%$ respectively. Bird bones were too fragmented to identify, while for mammals and fish 661 and 786 specimens were identified to the species level respectively.

\begin{tabular}{|l|l|c|c|}
\hline \multicolumn{2}{|c|}{ Species } & NISP & NISP, $\%$ \\
\hline Seal & Phocidae & 220 & 33.3 \\
\hline Boar & Sus scrofa & 163 & 24.7 \\
\hline $\begin{array}{l}\text { Aurochs/ } \\
\text { Bison }\end{array}$ & $\begin{array}{l}\text { Bos primigenius/ } \\
\text { Bison bonasus }\end{array}$ & 87 & 13.2 \\
\hline Elk & Alces alces & 58 & 8.8 \\
\hline Roe deer & Capreolus capreolus & 51 & 7.7 \\
\hline Dog & Canis lupus familiaris & 16 & 2.4 \\
\hline Horse & Equus caballus & 14 & 2.1 \\
\hline Fox & Vulpes vulpes & 11 & 1.7 \\
\hline Bear & Ursus arctos & 10 & 1.5 \\
\hline Marten & Martes martes & 10 & 1.5 \\
\hline Boar/pig & $\begin{array}{l}\text { Sus scrofa/ } \\
\text { S.s. domesticus }\end{array}$ & 4 & 0.6 \\
\hline Beaver & Castor fiber & 4 & 0.6 \\
\hline Red deer & Cervus elaphus & 3 & 0.5 \\
\hline Dog/wolf & $\begin{array}{l}\text { Canis lupus/Canis lupus } \\
\text { familiaris }\end{array}$ & 3 & 0.5 \\
\hline Badger & Meles meles & 3 & 0.5 \\
\hline $\begin{array}{l}\text { Mountain } \\
\text { hare }\end{array}$ & Lepus timidus & $\mathbf{6 6 1}$ & $\mathbf{1 0 0 . 0}$ \\
\hline Wolf & Canis lupus & & 0.3 \\
\hline Otter & Lutra lutra & 1 & 0.2 \\
\hline Total & & 1 & 0.2 \\
\hline
\end{tabular}

Table 7. Mammal bones at Šventoji 43. Analysed by G. Piličiauskienè.
Phocidae and boars were the most hunted animals at Šventoji 43 , as their share among the identified bones was $1 / 4$ or more (Table 7 ). Aurochs/ bison, elk and roe deer were also consumed in large numbers, while the bones of other mammal species do not exceed $2.5 \%$.

\begin{tabular}{|l|l|c|c|}
\hline \multicolumn{2}{|c|}{ Species } & NISP & NISP, \% \\
\hline Zander & Sander lucioperca & 290 & 36.9 \\
\hline Pike & Esox lucius & 259 & 33.0 \\
\hline $\begin{array}{l}\text { Pike/zan- } \\
\text { der }\end{array}$ & $\begin{array}{l}\text { Esox lucius/Sander } \\
\text { lucioperca }\end{array}$ & 121 & 15.4 \\
\hline Cyprinids & Cyrinidae & 98 & 12.5 \\
\hline Bream & Abramis brama & 13 & 1.7 \\
\hline Tench & Tinca tinca & 4 & 0.5 \\
\hline Turbot & Scophthalmus maximus & 1 & 0.1 \\
\hline Total & & $\mathbf{7 8 6}$ & $\mathbf{1 0 0 . 0}$ \\
\hline
\end{tabular}

Table 8. Fish bones at Šventoji 43. Analysed by G. Piličiauskienè.

Among fish bones zander and pike are dominant, with their bones constituting up to 36.9 and $33 \%$ of the fish bone assemblage respectively (Table 8 ). To this figure, one should also consider the $15.4 \%$ of bones classified as pike/zander. Cyprinids, such as bream and tench, were less important (14.7\%). No bones of anadromous fish species were identified and only a single bone of a marine fish, turbot, was found. Most zanders were $50-60 \mathrm{~cm}$ and pikes were $50-80 \mathrm{~cm}$ long. Fish vertebrae clearly prevailed against cranial bones regardless of the taxa. This is in sharp contrast to the fish bone assemblage from the lower archaeological layer B at Šventoji 4, which was dated to $3110 / 3000-3020 / 2930 \mathrm{cal}$ BC and mostly contained cranial bones of cyprinids (Piličiauskas 2016).

Zooarchaeological data at Šventoji 43 suggests a diverse economy based on several aquatic and terrestrial resources, such as seals, forest game and freshwater fish species. Domestic animals were not raised with the exception of dogs. All fishing took place in the lagoon or the lagoonal lake, which had 
to be completely fresh or only slightly brackish, as indicated by the identified fish taxa. The attempt to learn more about the salinity of Šventoji paleolagoon during the occupation of Šventoji 43 by measuring C and $\mathrm{N}$ isotope ratios has failed, since unburnt pike vertebras did not yield enough collagen for analysis (Table 9). However, stable isotope data obtained from fish bone collagen does exist for other Šventoji sites (Piličiauskas et al. 2017a; c). Significantly higher $\delta^{13} \mathrm{C}$ and $\delta^{15} \mathrm{~N}$ values of pike, perch and zander at Šventoji 4, when compared to the same species in inland lakes, suggest a strong sea influence and brackish water in the ancient lagoon. However, the available stable isotope data characterises the stage of the water basin, which existed ca. 700 years later than the settlement at Šventoji 43 and significant paleoenvironmental changes were likely during such a long period because of the flat topography and dynamic coastline.

A single newborn harp seal radius with cut marks, as well as the 15 cases of wild boar teeth eruptions are very important seasonal indicators at Šventoji 43. They confirm that people likely occupied the site during the spring. This corresponds with the spawning period of zander and pike and fits well with zooarchaeological data arguing for fishing that was mostly oriented to catching zander and pike. All evidence leads us to conclude that the site was used as a seasonal settlement. Šventoji 43 does not provide any arguments either for a highly specialized marineoriented economy or for year-round occupation. While people were attracted to the coast by the abundant lagoonal fish and seal resources as well as the availability of amber, the decision to live on the eastern bank of the lagoon rather than on the sandy spit was perhaps influenced by the intent to continue the exploitation of inland hunting grounds as well as other forest resources.

If we do not take into account the different recovery techniques of zooarchaeological remains, not many differences can be seen between the Comb
Ware culture site Šventoji 43 and sites about 700 years younger with Porous Ware, including Šventoji 23, $1,2 / 4$, and 6 . In every site seal bones make up the largest proportion in the mammal category. Seals are followed by wild boars and large forest ungulates (Stančikaitè et al. 2009) Therefore, it seems that the same type of economy continued in Šventoji until the appearance of Globular Amphora and Corded Ware people ca. $2700 \mathrm{cal}$ BC, when domestic animals and dairy products began to be incorporated into human diet (Robson et al. 2019).

\section{Bone collagen stable isotope data}

No graves or isolated human bones were found at Šventoji 43 with the exception of 2 deciduous teeth. Therefore, no stable isotope data for humans is available. However, bone collagen $\mathrm{C}$ and $\mathrm{N}$ isotope ratios of other mammals, including dogs, have been published by Piličiauskas et al. (2017c). These may be used as valuable proxy data about the economy of the site. All bone collagen stable isotope data, including unsuccessful measurements and unreliable values, are given in Table 9. Collagen extraction and stable isotope measurement procedures have already been described elsewhere (Piličiauskas et al. 2017c).

Plotted $\delta^{13} \mathrm{C}$ and $\delta^{15} \mathrm{~N}$ values of dogs and wolf from Šventoji 43, together with stable isotope data of dog and human bones from other MesolithicNeolithic Lithuanian sites (Fig. 19), provide the basis for several statements. First of all, it is clear that the diet of Subneolithic dogs was not the same as humans. Dogs were not only eating the waste of cooking remains, they were also fed by their masters, which we deduce from another significant finding that the diet of dogs in the Šventoji area during the Subneolithic was mostly aquatic and completely different from that of the wolves. Furthermore, diet of dogs during the Subneolithic was diverse and both of the two most distant examples are from 


\begin{tabular}{|c|c|c|c|c|c|c|c|c|c|}
\hline No & species & bone/tooth & spatial data & $\delta^{13} \mathrm{C}$ & $\delta^{15} \mathbf{N}$ & C:N & $\begin{array}{c}\text { Collagen } \\
\text { yields (\%) }\end{array}$ & $\% \mathrm{C}$ & $\% \mathrm{~N}$ \\
\hline 1 & $\begin{array}{l}\text { aurochs/ } \\
\text { bison }\end{array}$ & metacarpus distal epiphysis & No 1295 & -22.95 & 5.61 & 3.72 & 1.7 & 28.67 & 8.98 \\
\hline 2 & $\begin{array}{l}\text { aurochs/ } \\
\text { bison }\end{array}$ & calcaneus fragment & L-39, 8 level & -22.44 & 3.41 & 3.26 & 2.88 & 24.01 & 8.58 \\
\hline 3 & bear & lower molar & L-25, 8 level & -21.35 & 5.67 & 3.26 & 3.47 & 28.08 & 10.1 \\
\hline 4 & beaver & tooth & W2-34, 4 level & & & & 0.77 & & \\
\hline 5 & beaver & tooth & $M-33,4$ level & & & & 0.7 & & \\
\hline 6 & boar & talus & $L-31,5$ level & -23.31 & 5.57 & 6.31 & 0.72 & 6.33 & 1.17 \\
\hline 7 & boar/pig & scapula diaphysis & L-71, 6 level & & & & 1.02 & & \\
\hline 8 & boar/pig & humerus distal epiphysis & K-26, 6 level & -22.21 & 6.87 & 3.21 & 16.14 & 44.81 & 16.3 \\
\hline 9 & boar/pig & lower molar & O2-34, 5 level & -18.29 & 11.2 & 3.57 & 1.75 & 14.67 & 4.86 \\
\hline 10 & $\operatorname{dog}$ & lower molar & O-34, V level & & & & 0.19 & & \\
\hline 11 & $\operatorname{dog}$ & lower molar & T-33, 8 level & -23.83 & 13.9 & 3.48 & 2.2 & 12.46 & 4.18 \\
\hline 12 & $\operatorname{dog}$ & lower molar & $\mathrm{N}-34,5$ level & -16.62 & 13.4 & 3.26 & 0.79 & 41.11 & 14.7 \\
\hline 13 & elk & 1st phalanx distal epiphysis & L2-34, 6 level & -23.48 & 4.35 & 3.34 & 1.76 & 37.36 & 13.1 \\
\hline 14 & fox & Fox, lower molar & M2-33, 6 level & & & & 0.9 & & \\
\hline 15 & horse & Horse talus fragment & ploughed zone, test pit 201 & -24.68 & 5.68 & 3.5 & 1.02 & 25.65 & 8.54 \\
\hline 16 & horse & Horse tibia distal diaphysis & L-82, 9 level & -23.23 & 4.86 & 3.17 & 12.15 & 39.77 & 14.6 \\
\hline 17 & pike & 3 vertebra & K-35, 6 level, test pit 201 & & & & 0.04 & & \\
\hline 18 & roe deer & upper molar & P2-33, 6 level & & & & 0.62 & & \\
\hline 19 & roe deer & lower molar & K-29, 7 level & & & & 0.83 & & \\
\hline 20 & roe deer & mandible & No 1297 & -23.5 & 4.46 & 3.22 & 12.77 & 40.9 & 14.8 \\
\hline 21 & harbour seal & radius diaphysis & L2-34, 5 level & -19.53 & 11.2 & 4.85 & 1.79 & 7.32 & 1.76 \\
\hline 22 & grey seal & humerus diaphysis & T-33, 6 level & -16.92 & 11.7 & 3.38 & 2.02 & 23.74 & 8.18 \\
\hline 23 & harp seal & ulna distal part & I2-33, 7 level & -16.52 & 12.7 & 3.3 & 3.13 & 28.23 & 9.98 \\
\hline
\end{tabular}

Table 9. Stable isotope data obtained on animal bone collagen from Šventoji 43. Note the large number of samples which yielded too low collagen or whose C:N ratios fall outside the acceptable range of 2.9-3.6 (DeNiro 1985).

Such samples are indicated in Italics.

Šventoji 43. The dog with much less depleted $\delta^{13} \mathrm{C}$ value $(-16.6 \%$ ) was likely fed mainly seals, while the dog with more depleted $\delta^{13} \mathrm{C}$ value $(-23.8 \%$ ) must have consumed a large amount of inland freshwater fish. This surprisingly large difference between the two dogs at the same site was once attempted to be explained by different chronology of both dogs, suggesting that the dog bone with 'marine' signal $\left(\delta^{13} \mathrm{C}=-16.6 \%\right.$ ) was perhaps from a historical village (Piličiauskas et al. 2017c). A tooth of sheep/goat found at the very bottom of the plough zone at Šventoji 43 has been dated to $1682-1931 \mathrm{cal}$ AD (Table 6). However, the dog's tooth in question was in fact retrieved from the humous sand below the ploughed zone and, therefore, it should belong to the Comb Ware settlement as most of the other finds do.

The case of the dog with clear 'freshwater' signals $\left(\delta^{13} \mathrm{C}=-23.8 \%\right.$ ) is no less intriguing. It is highly unlikely that during 3900-3650 cal BC the Šventoji lagoon would have been transformed into a completely fresh water lake with fish stable isotope values identical to those of the inland lakes. There is no evidence for a regression of the Baltic Sea during this period (Piličiauskas et al. 2015). It is much more likely, that the dog with the more depleted $\delta^{13} \mathrm{C}$ value did not spend much of its life on the Baltic coast. It must have appeared at Šventoji 43 just before the end 


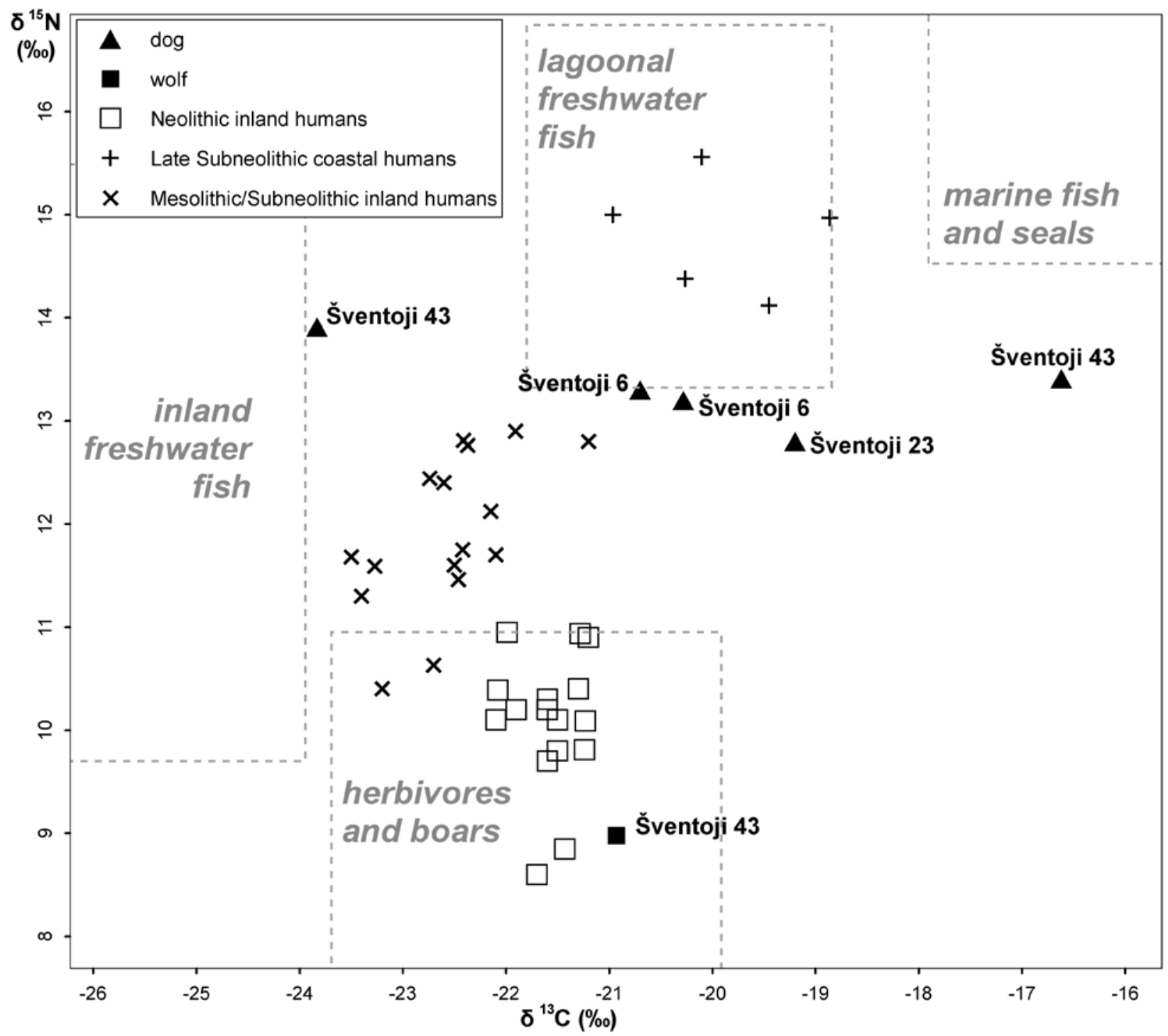

Fig. 19. Human, dog, and wolf $\delta^{13} \mathrm{C}$ and $\delta^{15} \mathrm{~N}$ bone collagen values from Lithuanian Mesolithic-Neolithic sites. Expected consumers' areas were estimated from Lithuanian and Latvian faunal stable isotope data (for more details see Piličiauskas et al. 2017a; c). Drawing by G. Piličiauskas.

of its life together with its master or as a gift. This case illustrates the possibility that for the larger part of the year the Comb Ware people resided further from the coast, while Šventoji 43 may have been visited only during a short period of the year.

\section{ARCHAEOLOGICAL DISCUSSION}

\section{Other Comb Ware sites in Lithuania}

In Šventoji area, Šventoji 43 is the only site dated to the beginning of the $4^{\text {th }}$ millennium BC and Comb Ware is the only pottery type known from that period. Only a single potsherd, which may be classified as Comb Ware, was found among younger materials 


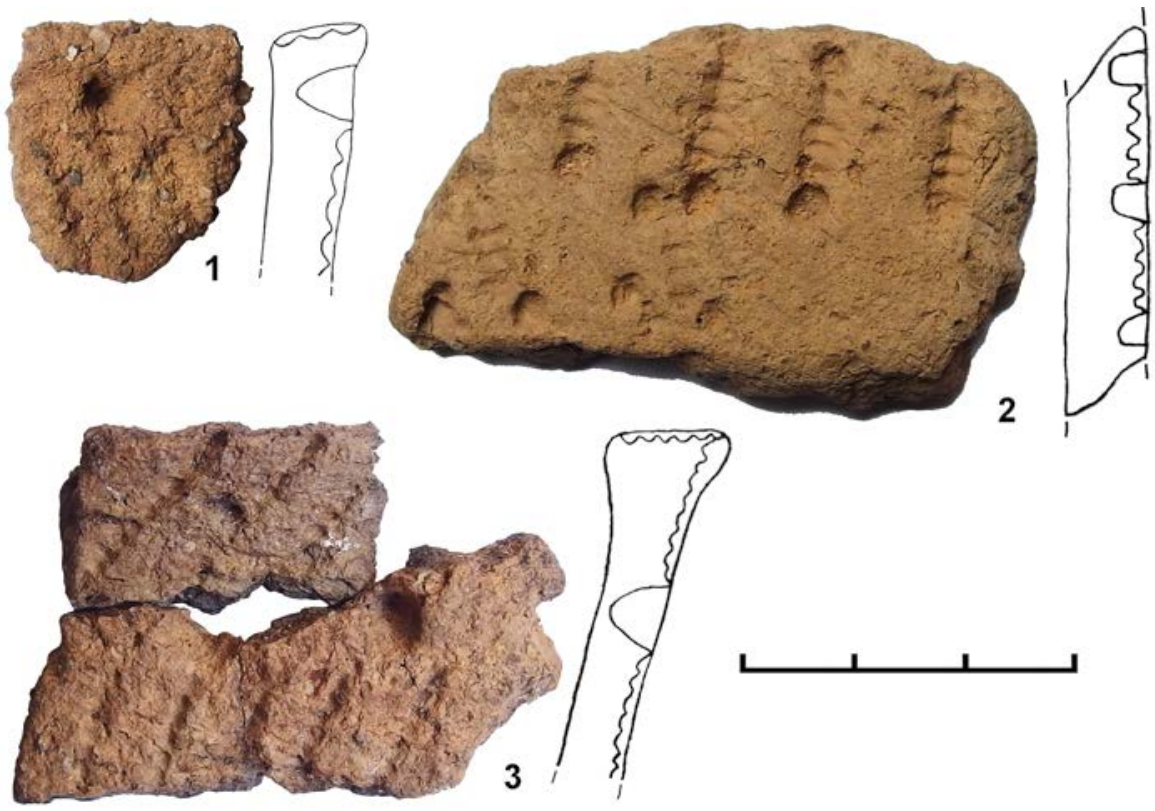

Fig. 20. Comb Ware potsherds from Jara 2 (1-2) and Šventoji 26 (3). Photo by G. Piličiauskas.

of Šventoji 26 site (Fig. 20:3). However, despite the scarcity of Comb Ware materials, the existing data indicates that the Comb Ware settlement at Šventoji 43 represents a separate phase of Comb Ware in coastal Lithuania rather than a sporadic episode of migration of a single Comb Ware community. Furthermore, the Comb Ware period had a great impact on cultural development. Comb-like Ware from Šventoji 26, probably dating to ca. $3300 \mathrm{cal} \mathrm{BC}$, demonstrates a continuation and transformation of the Comb Ware tradition on the Lithuanian coast (Piličiauskas 2016). Comb-like Ware vessels at Šventoji 26 were ornamented mainly with comb impressions, which sometimes were combined with pits that were, however, smaller and shallower than those at Šventoji 43. Šventoji 26 vessel rims are more protruded into the exterior than at Šventoji 43 (Rimantienè 2005, Abb. 354-356; Piličiauskas 2012, fig. 5:1).

On the other hand, the pottery sequence is different on the coast and in the area of Biržulis Lake, which is situated $90 \mathrm{~km}$ to the east from Šventoji. At Daktariške 5, Comb Ware is absent even though the stratified layer contains archaeological materials from the period of 4450-1600 cal BC, which also coincides with the chronology of Comb Ware. The oldest Subneolithic pottery at Daktariške 5 dates to the second part of the $5^{\text {th }}$ millennium cal BC and lacks comb ornamentation (Piličiauskas 2018, fig. 21). It should be classified as Narva Ware. Some sherds also demonstrate pitted patterns (Piličiauskas 2018, fig. 21:3) that resemble Karelian Pit-Comb ware (Tarasov et al. 2017, fig. 3). The pottery dated to $4^{\text {th }}$ millennium cal BC is comb-ornamented, but it has no pits and different profiles compared to the Comb Ware of Šventoji 43 (Piličiauskas 2018, fig. 22). Comb ornamented pottery at Daktariške 5 has many parallels with Šventoji 26 ceramics, which have already been mentioned above.

Apart from Šventoji 26 and 43, six more sites that bear pottery classified as Comb Ware are known in Northern Lithuania - Kretuonas 1, Jara 2 and 4, Pasuojè, Pašvitinys, and Žemaitiškè 2 (Fig. 1; Girininkas 2009). In Northeastern Lithuania, Comb Ware was tempered not only with organics like at Šventoji 43 or 26 (Fig. 20:2), but also with coarse 
crushed rock (Fig. 20:1). However, these assemblages are much smaller when compared to that of Šventoji 43. In inland areas Comb Ware was usually found together with other, much more numerous Subneolithic wares, such as Narva and Porous Ware. It is very difficult to say whether a separate phase of Comb Ware existed in North Eastern Lithuania or whether the producers of Comb Ware lived side by side with the producers of other pottery types or even whether Comb Ware vessels were imported to the settlements inhabited by the producers of Porous Ware.

\section{Origin of pottery and of Comb Ware on the Lithuanian coast}

Radiocarbon dates from the oldest potterybearing and the youngest aceramic sites confirm that the Comb Ware of Šventoji 43, dated to 3900-3650 cal $\mathrm{BC}$, is the oldest known pottery on the Lithuanian coast thus far. A charcoal sample from the clay fabric of a Subneolithic sherd at Nida site was dated to 3520-3140 cal BC (Piličiauskas, Heron 2015). Charred organic remains ('foodcrust') from Comb-like Ware vessel at Šventoji 26 were dated to 3697-3527 cal BC (Piličiauskas 2012), although the date may be older by several hundred years due to aquatic reservoir effects (Piličiauskas, Heron 2015). A charcoal from the lower archaeological layer at Šventoji 44, which is situated 950 meters north of Šventoji 43, was dated to Poz65421: 5330 35 ; 4328-3999 cal BC. The sample was taken from humous sand that contained charcoals and burnt bone fragments, but lacked potsherds (Piličiauskas 2016 ${ }^{3}$ ). Only two testpits, each $1 \times 1 \mathrm{~m}$ in size, were excavated there and perhaps pottery might be found if the larger area would be excavated. Seven kilometres south of Šventoji 43 , the aceramic site of Palanga was dated to $4440-3980$ cal BC. Here only bone and stone tools were found (Piličiauskas et al.
2015). Taking a glance at the Sārnate site, situated $120 \mathrm{~km}$ north from Šventoji, the earliest pottery type is also Comb Ware (Bērziņš 2008). It seems that the coastal people of the Šventoji region and perhaps also of the adjacent Latvian coast did not use pottery prior to ca. $4000 \mathrm{cal} \mathrm{BC}$ and the first pottery that was produced in this region was Comb Ware. But together with this statement, another two closely related questions arise: why did pottery appear on the Lithuanian coast so late and how did this process come to pass?

The appearance of pottery technology was dated to ca. 5200 cal BC in Estonia (Kriiska et al. 2017), ca. 5500 cal BC in Eastern Latvia (Лозe 1988), 4750 $\mathrm{cal}$ BC in Southern Scandinavia and $4750 \mathrm{cal} \mathrm{BC}$ in Polish Pomerania (Hartz, Lübke 2006; Terberger et al. 2009, p. 15). In Western Lithuania, particularly in the Biržulis Lake region, pottery was definitely produced ca. 4500 cal BC (Piličiauskas 2018). With the oldest pottery dated only to ca. $3900 \mathrm{BC}$ in coastal Lithuania and probably also the western Latvian coast, these areas would have been a kind of 'aceramic island' that was surrounded by pottery producing communities for more than 500 years. Due to some unknown reasons Mesolithic hunters-gatherers refused to adopt pottery technology during this period. Assuming that the Mesolithic economy in coastal Lithuania would have probably been oriented toward the exploitation of aquatic resources and knowing that the earliest ceramics produced by hunters-gatherers were preferably used for the processing of aquatic products (Jordan et al. 2016; Oras et al. 2017), the apparent absence of pottery before $3900 \mathrm{BC}$ seems unusual. However, very few coastal sites from the end of the Mesolithic have yet been discovered and excavated in Lithuania, and therefore little evidence for the exploitation of aquatic resources is available (Piličiauskas et al.2015). Current archaeological and

${ }^{3}$ In the paper by Piličiauskas (2016), two sites Šventoji 44 and 45 were confused. The radiocarbon-dated one was Šventoji 44 (i.e. a testpit No. 289) but not Šventoji 45. 
zooarchaeological data from the Mesolithic is very scarce and there is no stable isotope data. This makes the discussion on the possible delay of the adoption of pottery technology on the Lithuanian and Latvian coasts rather limited, yet an area that presents much potential in future research.

Cultural transmission, rather than migration, can be seen as the most plausible explanation for the spread of pottery across a large part of Eurasia, stretching from Denmark to Japan (Piezonka 2012; Jordan et al. 2016). Local Mesolithic roots of the flint industry at Šventoji 43 also favour the spread of pottery technology through contact, exogamy and copying. It is interesting to note that the spread of Typical Comb Ware to (at least some areas of) Finland and Estonia was probably different. Here the sudden shift toward pottery was accompanied by the extensive use of non-local flint and new lithic reduction techniques (Nordqvist 2018). The spread of Typical Comb Ware via the migration of large groups of people has recently been supported by ancient DNA data from Estonia and Latvia. It indicates that the Mesolithic/Narva Ware people differ genetically from the Comb Ware people with the former being closer to Western hunter-gatherers, while the latter are closer to the Eastern hunter-gatherers (Saag et al. 2017; Jones et al. 2017). In Lithuania, however, no graves, which might be assuredly assigned to the Comb Ware culture, have been discovered yet. Therefore, we cannot be certain about whether the Lithuanian Comb Ware producers are genetically linked to Estonian and Karelian Comb Ware producers or to local Mesolithic hunter-gatherers.

\section{Linguistic data. Finno-Ugric hydronyms in Lithuania}

56 river and lake names in Lithuania were described as more or less questionable Finno-Ugric hydronyms (Table 10; Vanagas 1981; 1988), which are traditionally associated with Comb Ware culture people (Rimantienè 1996; Girininkas 2000). This number is considerably smaller when compared with that of Finno-Ugric hydronyms in Latvia, where they are counted in hundreds (Rudzìte 1968; Bušs 2015), and where Finno-Ugric languages were still in use during the historical period. It is interesting to note, that the last Finno-Ugric speakers in Latvia, the Livonians, who have retained their language almost until today, have been living precisely on the Baltic coast (Kolga et al. 2001).

\begin{tabular}{|l|l|l|}
\hline No & \multicolumn{1}{|c|}{ name } & $\begin{array}{c}\text { water } \\
\text { body }\end{array}$ \\
\hline 1 & Agionè & river \\
\hline 2 & Agumas & river \\
\hline 3 & Alanga & river \\
\hline 4 & Ilma & lake \\
\hline 5 & Ilmėdas & lake \\
\hline 6 & Ymasta & river \\
\hline 7 & Jara & river \\
\hline 8 & Jarupys & river \\
\hline 9 & Kaivadys & river \\
\hline 10 & Kėvé & river \\
\hline 11 & Kidė & river \\
\hline 12 & Kirgas & river \\
\hline 13 & Kisė & river \\
\hline 14 & Kivė & river \\
\hline 15 & Kyvė & river \\
\hline 16 & Korubis & river \\
\hline 17 & Kūra & river \\
\hline 18 & Kvistė & river \\
\hline 19 & Lambis & river \\
\hline 20 & Lonas & river \\
\hline 21 & Luodis & lake \\
\hline 22 & Munas & lake \\
\hline 23 & Negasčius & lake \\
\hline 24 & Nevelis & river \\
\hline 25 & Pernava & river \\
\hline 26 & Pernokė & lake \\
\hline 27 & Piladis & river \\
\hline 28 & Puožas & \\
\hline
\end{tabular}

\begin{tabular}{|l|l|l|}
\hline No & \multicolumn{1}{|c|}{ name } & $\begin{array}{c}\text { water } \\
\text { body }\end{array}$ \\
\hline 29 & Robata & river \\
\hline 30 & Ruja & river \\
\hline 31 & Saidė & river \\
\hline 32 & Salaka & river \\
\hline 33 & Salakai & lake \\
\hline 34 & Suoja & river \\
\hline 35 & Suojys & lake \\
\hline 36 & Šakšys & lake \\
\hline 37 & Šiladis & river \\
\hline 38 & Šuoja & river \\
\hline 39 & Tarande & river \\
\hline 40 & Tervetė & river \\
\hline 41 & Tilka & river \\
\hline 42 & Ugra & river \\
\hline 43 & Umèja & river \\
\hline 44 & Virčiuvis & river \\
\hline 45 & Voǩ̌elis & lake \\
\hline 46 & ? Kurantas & river \\
\hline 47 & ? Kūra & river \\
\hline 48 & ? Kurys & river \\
\hline 49 & ? Langas & lake \\
\hline 50 & ? Liaude & river \\
\hline 51 & ? Livinta & river \\
\hline 52 & ? Sykė (Sikia) & river \\
\hline 53 & ? Suosa & river \\
\hline 54 & ? Suosa & lake \\
\hline 55 & ? Tatula & river \\
\hline 56 & ? Vykšius & lake \\
\hline
\end{tabular}

Table 10. Names of Lithuanian rivers and lakes for which a possible Finno-Ugric origin was described by Vanagas (1981) and other authors cited there. More questionable names are indicated by question marks. 
In the beginning of the $20^{\text {th }}$ century, FinnoUgric hydronyms identified in Lithuania were seen as evidence that in prehistory the entire country was inhabited by the ancestors of modern Finno-Ugric speaking people (Būga 1924). This view, however, changed in the $2^{\text {nd }}$ part of the $20^{\text {th }}$ century. Large quantities of new archaeological data coming from the extensive excavations of Subneolithic sites revealed large differences between Lithuanian Subneolithic pottery and the Comb Ware of Latvia or Estonia. Despite the fact that even more Finno-Ugric hydronyms have been identified in the territory of modern Lithuania, they have begun to be associated only with the Comb Ware culture in particular. They were interpreted as signs of sporadic Finno-Ugric migrations and of the existence of isolated FinnoUgric communities, surrounded by local people of Narva culture, who spoke a different language (Vanagas 1988; Rimantienè 1996; Girininkas 2000). Recently, this approach was indirectly supported by ancient DNA data, which revealed large genetic differences between the Comb Ware culture and earlier hunter-gatherers in the East Baltic (Saag et al. 2017). However, the distribution of Finno-Ugric hydronyms and morphometric data of the bodies of water, which have preserved those names, has raised some doubts.

When Finno-Ugric hydronyms are mapped together with known Comb Ware sites, a wider distribution of the former is evident. Only the southwestern part of the country has no Finno-Ugric hydronyms, while Comb Ware is known only from the northern part that is close to Latvia (Fig. 1). Two explanations are possible for this observation. Comb Ware materials still have to be discovered in the central part of the country. Otherwise, some FinnoUgric hydronyms were left by people who did not produce Comb Ware and probably used other pottery types or did not use it at all.

Another interesting observation that can be made about Finno-Ugric hydronyms is that almost all of them belong to very short rivers or small lakes. Only the Jara and Tatula rivers have lengths of 82 and $65 \mathrm{~km}$ respectively, while most of the others are tiny streams from one to a few kilometres long. Among the 13 lakes with Finno-Ugric names, only Luodis has water coverage of $13 \mathrm{sq}$. km, while others are much smaller lakes, with areas that usually do not exceed $1 \mathrm{sq} . \mathrm{km}$. Such small bodies of water had to have a particular economic, geographic or ritual significance for only very few people, perhaps just for a single community living closest to it. It may be assumed that FinnoUgric names of the larger bodies of water, which were important to larger number of people, did not survive. All this implies that Finno-Ugric hydronyms survived until today as they entered the new and evolving language during the assimilation of isolated Finno-Ugric communities. This also suggests that the actual extent of Finno-Ugric language must have been much larger than it is possible to define today by Finno-Ugric hydronyms. It should also be noted that many Finno-Ugric place names may have vanished due to the complete population replacements due to violence and new diseases brought in by arriving migrants. This scenario is consistent with genetic and archaeological data and is probable for some regions during the arrival of Corded Ware culture people in 2800-2400 cal BC (Mittnik et al. 2018; Piličiauskas 2018). Archaeological data, however, only attests the continuity in material culture between the Subneolithic and Neolithic for the Northeastern part of Lithuania. Finno-Ugric hydronyms are unknown from coastal Lithuania and the Biržulis Lake region where the especially numerous and rich Corded Ware culture sites were investigated and where Late Porous ware, which has continued Subneolithic pottery traditions into the Neolithic, was absent. Therefore, we would like to suggest that Finno-Ugric hydronyms in Lithuania should not be related exclusively with Comb Ware culture. The remains of this culture are too scarce to explain the existence of FinnoUgric hydronyms. Producers of Comb-like or even 
Porous Ware also could have spoken in Finno-Ugric languages. In order to strengthen this hypothesis, more genetic data is needed from the people who have produced various types of Subneolithic pottery. Although genetic data does not directly indicate the language spoken by a particular group of people, there are many historically documented instances of genes spreading along with language (Diamond 1999).

\section{CONCLUSIONS}

Šventoji 43 is the first known Comb Ware culture site on the Lithuanian coast, and it has been recently thoroughly investigated through a multidisciplinary approach. Our research has attested that the earliest pottery in this region was Comb Ware (rather than Narva Ware) and that its appearance is dated 7001000 years later when compared to other areas around the Baltic. Šventoji 43 suggests that a separate phase of Comb Ware production existed in coastal Lithuania and that it predates all other Subneolithic pottery types known in Šventoji. The finds of this study, therefore, call for a careful reconsideration of the pottery sequence for this region. Our research supports the idea that technology of the production of point or round-base ceramic vessels spread through the vast territories of Asia and Eastern Europe via cultural contact, which also involved some exchange of people themselves by exogamy, and the process itself was accelerated by the growing importance of aquatic foods (Nunez 1990; Jordan et al. 2016; Kriiska et al. 2017). An extensive contact network of East European hunters-gatherers has become especially evident after $4000 \mathrm{cal} \mathrm{BC}$, when the extraction of amber in large quantities became available on the Southeastern Baltic coast. Furthermore, a linear frontier of the spreading technology of pottery did not exist and some Mesolithic societies delayed the adoption of pottery until ca. $4000 \mathrm{cal}$ BC.

Specific morphometric data and a distribution of hydronyms of Finno-Ugric origin in Lithuania can hardly be explained by sporadic migrations of Comb Ware culture people. We would like to suggest that people producing other Subneolithic pottery types may also have spoken in Finno-Ugric languages.

\section{Acknowledgements}

Authors would like to thank the landowner Valdis Flaksas for permission to carry out excavations at Šventoji 43. We are also thankful to the two anonymous reviewers and Annette Hansen for their useful remarks and comments that helped improve the quality of this manuscript.

\section{REFERENCES}

Ahola, M., 2017. The material culture of Finnish Stone Age hunter-gatherer burials. Fornvännen, 112, 201-215.

Berggren, G., 1969. Atlas of Seeds and Small Fruits of Northwest-European Plant Species with Morphological Descriptions. Part 2, Cyperaceae. Stockholm: Swedish Museum of Natural History.

Berggren, G., 1981. Atlas of Seeds and Small Fruits of Northwest-European Plant Species with Morphological Descriptions. Part 3, SalicaceaeCruciferae. Stockholm: Swedish Museum of Natural History.

Bērzin̄š, V., 2008. Sārnate: living by a coastal lake during the East Baltic Neolithic, Acta Universitatis Ouluensis B, Humaniora 86. Oulu: Oulu University Press.

Bērziņš, V., Ceriṇa, A., Kalniņš, M., Lõugas, L., Lübke, H., Meadows, J., 2016. Priedaine: a Neolithic site at the Gulf of Riga. Archaeologia Baltica, 23, 12-37.

Būga, K., 1924. Aisčiu praeitis vietų vardų šviesoje. Kaunas: Valstybès sp.

Bušs, O., 2015. The Finno-Ugric influence on the Latvian place names: the history of the research and current challenges. Yearbook of Finno-Ugric Studies, 2, 50-56. 
Butrimas, A., 2016. Biržulis. Medžiotojai, žvejai ir senieji žemdirbiai X-II tūkstantmetyje pr. Kr. II. Gintaras. Vilnius: Vilniaus dailès akademijos leidykla.

Cappers, R. T. J., Bekker, R. M., Jans, J. E. A., 2006. Digital Seed Atlas of the Netherlands. Groningen: Barkhuis Publishing \& Groningen University Library.

DeNiro, M. J., 1985. Postmortem preservation and alteration of in vivo bone collagen isotope ratios in relation to paleodietary reconstruction. Nature, 317, 806-809.

Diamond, J., 1999. Guns, Germs, and Steel: the Fates of Human Societies. New York, London: W. W. Norton \& Company.

Girininkas, A., 2000. Baltai prie Suomijos illankos. Lietuvos archeologija, 19, 103-108.

Girininkas, A., 2009. Lietuvos Archeologija. T.1. Akmens amžius. Vilnius: Versus aureus.

Grigas, A., 1986. Lietuvos augalu vaisiai ir sèklos. Vilnius: Mokslas.

Hartz, S., Lübke, H., 2006. New evidence for a chronostratigraphic division of the Ertebølle culture and the earliest funnel beaker culture on the Southern Mecklenburg Bay. In: Kind, C. J., ed. After the Ice Age. Settlements, Subsistence and Social Development in the Mesolithic of Central Europe (=Materialhefte zur Archäologie in Baden-Württemberg, 78.). Stuttgart: Theiss, 61-77.

Jones, E. R., Zarina, G., Moiseyev, V., Lightfoot, E., Nigst, P. R., Manica, A., Pinhasi, R., Bradley, D. G., 2017. The Neolithic Transition in the Baltic Was Not Driven by Admixture with Early European Farmers. Current Biology, 27(4), 576-582.

Jordan, P., Gibbs, K., Hommel, P., Piezonka, H., Silva, F., Steele, J., 2016. Modelling the diffusion of pottery technologies across Afro-Eurasia: emerging insights and future research. Antiquity, 90(351), 590-603.

Kolga, M., Tõnurist, I., Vaba, L., Viikberg, J., 2001. The red book of the peoples of the Russian empire. Tallinn: Estada Kirjastus.
Kriiska, A., 2015. Foreign materials and artefacts in the $4^{\text {th }}$ and $3^{\text {rd }}$ millennia BCE Estonian Comb Ware Complex. In: Espak, P., et al. eds. When gods spoke: researches and reflections on religious phenomena and artefacts. Studia in honorem Tarmo Kulmar. Tartu: University of Tartu Press, 107-124.

Kriiska, A., Oras, E., Lõugas, L., Meadows, J., Lucquin, A., Craig, O.E., 2017. Late Mesolithic Narva stage in Estonia: pottery, settlement types and chronology. Estonian Journal of Archaeology, 21(1), 52-86.

Kulkova, M., Mazurkevich, A., Gerasimov, D., 2016. Stone Age Archaeological Sites and Environmental Changes during the Holocene in the NW Region on Russia. In: Harff, J., Bailey, G., Lüth, F., eds. Geology and Archaeology: Submerged Landscapes of the Continental Shelf. London: The Geological Society, 27-49.

Larsson, L., 1990. The Mesolithic of Southern Scandinavia. Journal of World Prehistory, 4 (3), 257-309.

Mittnik, A., Wang, C.-C., Pfrengle, S., Daubaras, M., Zarina, G., Hallgren, F., Allmäe, R., Khartanovich, V., Moiseyev, V., Furtwängler, A., Valtueña, A. A., Feldman, M., Economou, C., Oinonen, M., Vasks, A., Tõrv, M., Balanovsky, O., Reich, D., Jankauskas, R., Haak, W., Schiffels, S., Krause, J., 2018. The genetic prehistory of the Baltic Sea region. Nature Communication, 9 (442), doi:10.1038/s41467-018-02825-9.

Mökkönen, T., Nordqvist, K., 2017. Kierikki Ware and the contemporary Neolithic asbestos- and organic-tempered potteries in north-east Europe. Fennoscandia Archaeologica, XXXIV, 83-116.

Nordqvist, K., 2018. The Stone Age of northeastern Europe 5500-1800 cal BC. Bridging the gap between the East and the West (Doctoral Dissertation). Acta Univ. Oul. B 160. University of Oulu, Finland. Tampere: Juvenes Print.

Nordqvist, K., Herva, V.-P., Ikäheimo, J., Lahelma, A., 2012. Early copper use in Neolithic 
north-eastern Europe: an overview. Estonian Journal of Archaeology, 16(1), 3-25.

Nunez, M., 1990. On Subneolithic pottery and its adoption in Late Mesolithic Finland. Fennoscandia archaeologica, VII, 27-52.

Oras, E., Lucquin A., Lembi L., Tõrv M., Kriiska A., Craig O. E., 2017. The adoption of pottery by northeast European hunter-gatherers: evidence from lipid residue analysis. Journal of Archaeological Science, 78, 112-119.

Piezonka, H., 2012. Stone Age hunter-gatherer ceramics of north-eastern Europe. New insights into the dispersal of an essential innovation. Documenta Praehistorica, 39, 23-51.

Piličiauskas, G., 2012. Lietuvos neolito ir ankstyvojo metalų laikotarpio chronologija naujų radiometrinių datų šviesoje. Lietuvos archeologija, 38, 11-52.

Piličiauskas, G., 2016. Lietuvos pajūris subneolite ir neolite. Žemès ūkio pradžia. Lietuvos archeologija, 42, 25-103.

Piličiauskas, G., 2018. Virvelinès keramikos kultūra Lietuvoje 2800-2400 cal BC. Vilnius: Lietuvos istorijos institutas.

Piličiauskas, G., Heron, C., 2015. Aquatic radiocarbon reservoir offsets in the Southeastern Baltic. Radiocarbon, 57(4), 539-556.

Piličiauskas, G., Jankauskas, R., Piličiauskienė, G., Craig, O. E., Charlton, D., Dupras, T., 2017a. The transition from foraging to farming $(7000-500 \mathrm{cal} \mathrm{BC})$ in the SE Baltic: A re-evaluation of chronological and palaeodietary evidence from human remains. Journal of Archaeological Science: Reports, 14, 530-542.

Piličiauskas, G., Kisielienè, D., Piličiauskienè, G., 2017b. Deconstructing the concept of Subneolithic farming in the southeastern Baltic. Vegetation history and archaeobotany, 26(2), 183-193.

Piličiauskas, G., Luik, H., Piličiauskienè, G., 2015. Reconsidered Late Mesolithic and Early Neolithic of the Lithuanian coast: the Smelte and Palanga sites. Estonian journal of archaeology, 19(1), 3-28.
Piličiauskas, G., Mažeika, J., Gaidamavičius, A., Vaikutienè, G., Bitinas, A., Skuratovič, Ž., Stančikaitè, M., 2012. New Archaeological, Paleoenvironmental, and ${ }^{14} \mathrm{C}$ Data from the Šventoji Neolithic Sites, NW Lithuania. Radiocarbon, 54(3-4), 1017-1031.

Piličiauskas, G., Piličiauskienè, G., Jankauskas, R., Dupras, T., 2017c. Reconstructing Subneolithic and Neolithic diets of the inhabitants of the SE Baltic coast (3100-2500 cal BC) using stable isotope analysis. Archaeological and Anthropological Sciences, 9(7), 1421-1437.

Retallack, G. J., 1984. Completeness of the rock and fossil record: some estimates using fossil soils. Paleobiology, 10, 59-78.

Rimantienè, R., 1979. Šventoji. Narvos kultūros gyvenvietès, Vilnius: Mokslas.

Rimantienè, R., 1980. Šventoji. Pamarių kultūros gyvenviete, Vilnius: Mokslas.

Rimantienè, R., 1984. Akmens amžius Lietuvoje. Vilnius: Mokslas.

Rimantienè, R., 1996. Akmens amžius Lietuvoje. Vilnius: Žiburio leidykla.

Rimantienè, R., 2005. Die Steinzeitfischer an der Ostseelagune in Litauen, Vilnius: Litauisches Nationalmuseum.

Robson, H. K., Skipitytè, R., Piličiauskienè, G., Lucquin, A., Heron, C., Craig, O. E., Piličiauskas, G., 2019. Diet, cuisine and consumption practices of the first farmers in the south-eastern Baltic. Archaeological and Anthropological Sciences, 11(8), 4011-4024.

Rudzīte, M., 1968. Somugriskie hidronīmi Latvijas PSR teritorijā. Latviešu leksikas attīstība. [Latvijas Universitātes] Zinātniskie raksti, 86, 175-198.

Saag, L., Varul, L., Scheib, C.L.,Stenderup, J., Allentoft, M. E., Saag, L., Pagani, L., Reidla, M., Tambets, K., Metspalu, E., Kriiska, A., Willerslev, E., Kivisild, T., Metspalu, M., 2017. Extensive Farming in Estonia Started through a Sex-Biased Migration from the Steppe. Current Biology, 27(14), 2185-2193.

Sander, K., Kriiska, A., 2018. New archaeological data and paleolandscape reconstructions of the basin 
of an Early and Middle Holocene lake near Kunda, North-Eastern Estonia. Fennoscandia Archaeologica, XXXV, 65-85.

Sobkowiak-Tabaka, I., 2015. Lithic industry of the Late Mesolithic and Early Neolithic communities from Dąbki sites 9 and 10. In: Kabaciński, J., Hartz, S., Raemaekers, D. C. M., Terberger, T., eds. The Dąbki Site in Pomerania and the Neolithisation of the North European Lowlands (c. 5000-3000 calBC). Archäologie und Geschichte im Ostseeraum. Rahden/Westf: Verlag Marie Leidorf GmbH, 233-272.

Stančikaite, M., Daugnora, L., Hjelle, K., Hufthammer, A. K., 2009. The environment of the Neolithic archaeological sites in Šventoji, Western Lithuania. Quaternary international, 207(1-2), 117-129.

Tarasov, A., Nordqvist, K., Mokkonen, T., Khoroshun, T., 2017. Radiocarbon chronology of the Neolithic-Eneolithic period in Karelian Republic (Russia). Documenta Praehistorica, 44, 98-121.

Terrberger, T. S., Hartz, J.K., Kabaciński, J., 2009. Late hunter-gatherer and early farmer contacts in the southern Baltic - a discussion. In: Glørstad, H., Prescott C., eds. Neolithisation as if History Mattered: Processes of Neolithisation in North-Western Europe. Lindome: Bricoleur Press, 257-298.

Vanagas, A., 1981. Lietuvių hidronimu etimologinis žodynas. Vilnius: Mokslas.
Vanagas, A., 1988. Lietuvių vandenvardžiai. Vilnius: Mokslas.

Wąs, M., 2016. Krzemień pomorski w pradziejach Pomorza Gdańskiego. In: Borkowski, W., Sałaciński, B., Sałaciński, S., eds. Krzemień narzutowy w pradziejach (= Studia nad gospodarka surowcami krzemiennymi $w$ pradziejach 8 ). Warszawa: Panstwowe Muzeum Archeologiczne, 43-63.

Zhulnikov, A., 2008. Exchange of amber in northern Europe in the III millennium BC as a factor of social interactions. Estonian Journal of Archaeology, 12, 3-15.

Ванкина, Л. В., 1970. Торфяниковая стоянка Сарнате. Рига: Зинатне.

Янитс, Л. Ю., 1959а. Неолитическое поселение Валма. In: Тараканова, С. А., Терентьева, Л. Н., еds. Вопросы этнической истории Прибалтики по данным археологии, этнографии и антропологии. Москва: Изд-во Академии наук СССР, 32-75.

Янитс, Л. Ю., 1959b. Поселения эпохи неолита и раннего металла в приустье р. Эмайыги (Эстонская ССР). Таллинн: Академия наук Эстонской ССР.

Лозе, И. Л., 1988. Поселения каменного века Лубанской низины. Мезолит, ранний и средний неолит. Рига: Зинатне.

\title{
ŠUKINĖS-DUOBELINĖS KERAMIKOS KULTŪRA LIETUVOJE. NAUJI DUOMENYS IŠ ŠVENTOSIOS 43
}

\author{
Gytis Piličiauskas, Dalia Kisielienè, Giedrė Piličiauskienė, Lukas Gaižauskas, \\ Algirdas Kalinauskas
}

\section{Santrauka}

Iki 2013 m. Lietuvoje buvo žinomos vos septynios Šukinès-duobelinès keramikos kultūros radimvietès, todèl šios kultūros įtaka vietinei kultūrų raidai iki šiol laikyta minimalia. 2013-2014 m. buvo rasta ir tyrinèta nauja šios kultūros gyvenvietė Lietuvoje - Šventoji 43. Ištirti $67 \mathrm{~m}^{2}$ sudaro mažesnę už $1 / 10$ gyvenvietès dalį. Beveik visas archeologinis sluoksnis išsijotas per $4 \mathrm{~mm}$ akies sietus, atlikti 
makrobotaniniai, zooarcheologiniai, izotopiniai tyrimai, AMS ${ }^{14} \mathrm{C}$ datavimas, o visų jų rezultatai yra pristatomi šiame straipsnyje.

Šventosios 43 gyvenvietės archeologinị sluoksnị sudare apie $30 \mathrm{~cm}$ storio durpé ir (arba) durpingas smèlis. Radiniai telkèsi gyvenamojoje zonoje, dviejose vos matomose kalvelèse, iškilusiose buvusio lagūninio ežero rytinèje pakrantèje. Abiejose jie vienalaikiai, o pastatų liekanų nerasta. Kaulų išliko, tačiau jie prastos būklès. Kultūrinių augalų liekanų ir naminių gyvulių kaulų, išskyrus šuns, nebuvo. Keramika labai homogeniška ir kitokia nei visų iki šiol tyrinètų Šventosios radimviečių - klasifikuota kaip šukinè-duobelinè.

Gyvenvietèje buvo gaminti gintariniai kabučiai, keturkampès ir apvalios sagutės, žiedai ir vamzdeliniai karoliai. Titnago įrankiai daryti iš vietinių pajūrio titnago rieduliukų, skaldytų daugiausia dvipoline technika. Skirtingai nuo Latvijos, Estijos ir Suomijos Šukinės-duobelinės keramikos kultūros gyvenviečių, Šventojoje 43 nenaudota bifasinè technika, tačiau iš netaisyklingų skeltelių gaminti mikrolitai, o tai liudija mezolito tradicijų tęstinumą titnago inventoriuje. Smiltainio galąstuvai ir akmeninių kaltų fragmentai rodo plačiai naudotus gludintus kertamuosius dirbinius, taip pat pagamintus iš skalūno ir atgabentus iš Suomijos. Radiokarboniniu metodu gyvenvietè datuota 3900-3650 cal BC, ir tai atitinka tipiškos šukinès-duobelinès keramikos laikotarpi Suomijoje ir Estijoje (4000-3400 cal BC). Zooarcheologiniai ir izotopiniai kaulų kolageno tyrimai atskleidè, kad gyvenvietè buvusi sezoninè, naudota pavasarị, medžioti miško žvèrys ir ruoniai, žvejota lagūniniame ežere, daugiausia - sterkai ir lydekos.

Šventosios 43 gyvenvietès medžiaga, taip pat vèlesnèse gyvenvietėse (Šventoji 26) aptikti šukinęduobelinę keramiką primenantys indai leidžia manyti, kad Lietuvos pajūryje buvo atskiras šukinès-duobelinès keramikos laikotarpis, ir Šukinès-duobelinès keramikos kultūros neišeina paaiškinti tik pavieniais jos gamintojų migracijų atvejais, nepalikusiais jokio pėdsako tolimesneje kultūros raidoje. Taip pat vis daugiau argumentų atsiranda paremti hipotezei, kad būtent šukinè-duobelinė keramika, o ne Narvos kultūros, buvo pati pirmoji keramika, pradèta gaminti Lietuvos, galbūt ir Latvijos pajūryje. Atrodo, kad bent 500 metų šiame regione gyveno medžiotojai-rinkejjai, kurie negamino keramikos, nors jų kaimynai tai darè. Tęstinumas titnago inventoriuje rodo, kad keramikos gamybos technologijos plito kultūrinių kontaktų būdu, o ne dèl masinès migracijos.

Lietuvoje yra žinomi bent 56 upių ir ežerų vardai, kurių kilmè gali būti finougriška. Šiandien jie yra siejami būtent su Šukinès-duobelinès kultūros gyvenvietėmis, šios kultūros žmonių migracija. Tačiau platesnis finougriškų hidronimų paplitimas už šukinès-duobelinès keramikos gyvenviečių leidžia kelti hipotezę, kad finougrų kalbomis galèjo kalbèti ir žmonès, gaminę kitų tipų subneolitinę keramiką.

\section{LENTELIŲ SĄRAŠAS}

1 lent. Šventosios 43 gyvūnų kaulų kolageno stabiliųjų izotopų duomenys. Atkreiptinas demesys $\mathfrak{i}$ didelị skaičių mėginių, kurie turèjo per mažai kolageno arba kurių $\mathrm{C}: \mathrm{N}$ santykis buvo už priimtino 2,9-3,6 intervalo ribų (DeNiro 1985). Tokie mèginiai išskirti pasvirusiu šriftu.

2 lent. Šventosios 43 augalų makroliekanų analizès rezultatai. Tyré D. Kisieliené.

3 lent. Šventosios 43 gintaro radiniai.

4 lent. Šventosios 43 gintaro papuošalų tipai.

5 lent. Šventosios 43 titnago dirbiniai ir gamybos atliekos.

6 lent. Šventosios 43 nesilicitinių uolienų radiniai. Uolienas nustate A. Kalinauskas, padedamas geologo G. Motuzos-Matuzevičiaus.

7 lent. Šventosios 43 radiokarbono datos.

8 lent. Šventosios 43 žinduolių kaulai. Tyré G. Piličiauskiené.

9 lent. Šventosios 43 žuvų kaulai. Tyrè G. Piličiauskiené. 
10 lent. Tikètinai finougriškos kilmès Lietuvos upių ir ežerų vardai, kurie nurodyti Aleksandro Vanago (1981) ir šioje knygoje cituojamų autorių. Labiau abejotini pažymèti klaustukais.

\section{ILIUSTRACIJŲ SĄRAŠAS}

1 pav. Šukinès-duobelinès keramikos radimvietès ir finougriški hidronimai Lietuvoje. Labiau tikètini hidronimai išskirti tamsesne spalva. Orientavimuisi pažymetas ir Biržulio ežeras, nors jo apylinkèse šukinès-duobelinès keramikos nebuvo rasta. Hidronimai pažymèti pagal Aleksandrą Vanagą (1988). G. Piličiausko brèž.

2 pav. Šventosios 43 ir kitų Šventosios regiono archeologinių radimviečių, datuojamų 6000$500 \mathrm{cal} \mathrm{BC}$, situacija. Žemèlapis sudarytas remiantis LiDAR duomenimis. G. Piličiausko brëž.

3 pav. Šurfų ir perkasų situacija Šventojoje 43 ir jūrinio smèlio paviršiaus topografija. G. Piličiausko brěž.

4 pav. Šventosios 43 vaizdas tiriant 2-ą perkasą. G. Piličiausko nuotr.

5 pav. Stratigrafijos aukštesneje gyvenvietės dalyje pavyzdys. G. Piličiausko nuotr.

6 pav. 1-os perkasos šiaurinès sienelès pjūvis egzageruotas vertikaliai 3,5 karto; pažymètos makrobotaninių tyrimų (M1-5) ir radiokarboninio datavimo mèginių vietos. G. Piličiausko brèž.

7 pav. 2-os perkasos vakarinès sienelès pjūvis egzageruotas vertikaliai 3,5 karto; pažymètos titnago mikrolitų (kryželiai) ir radiokarboninio datavimo (apskritimai) vietos. Litologiniai simboliai paaiškinti 6 pav. G. Piličiausko brëž.

8 pav. Stratigrafijos žemesnèje gyvenvietės dalyje pavyzdys. G. Piličiausko nuotr.

9 pav. Keramikos (gramai 0,25 $\mathrm{m}^{2}$ ) ir titnago mikrolitu paplitimas ant jūrinio smèlio paviršiaus topografijos pagrindo. Titnago, kitų uolienų, gintaro, sudegusių ir nesudegusių kaulų paplitimas atitinka keramikos paplitimą dviejose kalvelèse. G. Piličiausko ir L. Gaižausko brëž.

10 pav. Šventosios 43 šukinè-duobelinè keramika. G. Piličiausko nuotr.

11 pav. Šventosios 43 gintaro papuošalai ir jų ruošiniai: kūgio pavidalo sagutès su $\mathrm{V}$ tipo skylutemis $(1,3-4)$, kvadratinè sagute be skylučių (2), trapecijos pavidalo kabučiai (5-7), žiedas (8), vamzdeliniai karoliai (9-10). G. Piličiausko nuotr.

12 pav. Šventosios 43 titnago radiniai. G. Piličiausko pieš.

13 pav. Šventosios 43 nesilicitinių uolienų dirbiniai: smiltainio tinklų pasvarai (?) (1-2), metaporfyrito priekalas-galąstuvas (3), smiltainio priekalo fragmentas (4), smiltainio muštukas-priekalas (5), kvarcito muštukas-galąstuvas (6), smiltainio poliravimo plyta (7), smiltainio šlifavimo plyta (8), smiltainio muštukas (9), kvarcito muštukas (10). Raudonomis rodyklèmis pažymètos išdaužytos vietos, juodomis poliruotos arba šlifuotos. G. Piličiausko nuotr.

14 pav. Gludintų kaltų (ir kirvių?), pagamintų iš ivairių nesilicitinių uolienų, fragmentai: diabazas (1), porfyritas (2), skalūnas (3). G. Piličiausko nuotr. 15 pav. Šventosios 6 ir 26 radimviečiu skalūno (2-4) ir Onegos metatufo $(1,4)$ dirbiniai. G. Piličiausko nuotr.

16 pav. Šventosios 43 kaulinių dirbinių fragmentai. G. Piličiausko nuotr.

17 pav. Šventosios 43 kalibruotos ir modeliuotos radiokarboninès datos. G. Piličiausko brèž.

18 pav. Pirmosios apgyvendinimo fazès trukmè Šventojoje 43. G. Piličiausko brëž.

19 pav. Lietuvos mezolito-neolito radimviečiu žmonių, šunų ir vilko kaulų kolageno $\delta^{13} \mathrm{C}$ ir $\delta^{15} \mathrm{~N}$ vertès. Tikètinos vartotojų verčių zonos pažymètos remiantis Lietuvos ir Latvijos subneolito radimviečiu gyvūnijos stabiliųjų izotopų duomenimis (daugiau apie tai Piličiauskas et al. 2017a; c). G. Piličiausko brèž.

20 pav. Šukinè-duobelinè keramika iš Jaros $2(1-2)$ ir Šventosios 26 (3) radimviečių. G. Piličiausko nuotr. 